\title{
Influence of structural, textural and chemical parameters of silver zeolites on the retention of methyl iodide
}

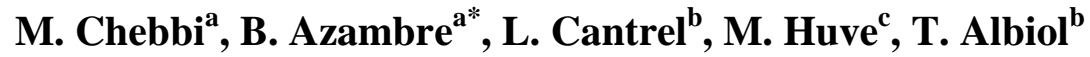 \\ ${ }^{a}$ Université de Lorraine, Laboratoire de Chimie et Physique-Approche Multi-Echelle des \\ Milieux Complexes (LCP-A2MC-EA n ${ }^{\circ} 4362$ ), Institut Jean-Barriol FR2843 CNRS, Rue \\ Victor Demange, 57500 Saint-Avold, France \\ ${ }^{b}$ Institut de Radioprotection et de Sûreté Nucléaire (IRSN), PSN-RES, Saint-Paul Lez.
} Durance, 13115, France.

${ }^{c}$ Unité de Catalyse et Chimie du Solide (UCCS), UMR 8181, Université Lille Nord de France, USTL, Villeneuve d'Ascq F-59655, France.

*corresponding author: e-mail address: bruno.azambre@univ-lorraine.fr

\begin{abstract}
An experimental screening of silver-exchanged zeolites towards the trapping of methyl iodide was carried out with the general aim of limiting as much as possible the iodine release in case of severe nuclear accident. Hence, a systematic study was implemented in order to better understand the effects of some important parameters such as the zeolite structural type (FAU$\mathrm{X}$ and $\mathrm{Y}, \mathrm{MOR},{ }^{*} \mathrm{BEA}, \mathrm{MFI}$ and FER) and chemical properties (namely the silver content and its speciation) on the adsorption behaviour. Characterization of 18 zeolitic sorbents, before or after iodine retention tests, was performed using elemental analyses, $\mathrm{N}_{2}$ porosimetry at -196 ${ }^{\circ} \mathrm{C}, \mathrm{XRD}, \mathrm{DR}-\mathrm{UV}-\mathrm{V}$ is spectroscopy and TEM. The distribution of silver species, namely as isolated $\mathrm{Ag}^{+}$cations or charged clusters in the internal porosity, and/or to a lesser extent as
\end{abstract}


metallic nanoparticles, was found to depend mainly on the zeolite structural type and the $\mathrm{Si} / \mathrm{Al}$ ratio and to a lesser extent on silver content.

$\mathrm{CH}_{3} \mathrm{I}$ retention properties were evaluated from dynamic adsorption tests carried out at $100^{\circ} \mathrm{C}$. Quantitative exploitation of breakthrough curves showed that the silver faujasite zeolites of the $\mathrm{Y}$ type $(\mathrm{Si} / \mathrm{Al}$ ratio $=2.5)$ with more than $15 \mathrm{wt} \%$ silver were the most efficient in order to achieve high adsorption capacities both at breakthrough and saturation. More generally, it is found that dispersed silver entities efficiently catalyze the dissociation of $\mathrm{CH}_{3} \mathrm{I}$ and the production of AgI precipitates.

Keywords: Nuclear applications, Faujasite, Iodine, Breakthrough curves, Adsorption, Diffusion.

\section{Introduction}

The capture of radioactive fission products in the context of severe nuclear accident is a major issue for safe nuclear energy. In the course of an accidental sequence, radiotoxic iodine species may be released from the degraded fuel and reach the nuclear containment building via the Reactor Coolant System (RCS). In most of nuclear power plants, a venting system is implemented with the aim of maintaining the integrity of the containment in case or overpressure. These containment venting systems (CVS) could be equipped with a filtration device to limit the external release of radioactive fission products [1]. Among these species, iodine is a significant contributor owing to its ability to exist as volatile species (namely $\mathrm{I}_{2}$ and $\left.\mathrm{CH}_{3} \mathrm{I}\right)$, radiological consequences linked with its involvement in human metabolic processes and high mobility in environment [2,3].

After the Fukushima accident, one of the main concerns of the nuclear industry has been to review the mitigation strategies which could be employed to limit the radiological 
consequences of a severe accident. An efficient solution may consist in combining existing filtration devices (such as metallic filters, aqueous scrubbers or sand bed filters [4]) with an additional filtration stage which can be made of inorganic porous adsorbent. Among the possible adsorbing materials, zeolites are obvious candidates, thanks to their thermal stability and radiation resistance, high specific surface areas, tunable pore size and chemistry [5]. In past works, silver-exchanged faujasite zeolites were identified as the most efficient adsorbents towards both $\mathrm{I}_{2}$ and $\mathrm{CH}_{3} \mathrm{I}$ while zeolitic sorbents containing other cations (lead, copper, manganese, palladium...) were found less promising [6]. This is explained by the very high affinity of silver for iodine to form thermally stable AgI precipitates. By now, most of academic and industrial research works were focused on $\mathrm{Ag}$ /zeolites with faujasite $\mathrm{X}$ or mordenite structures $[7,8]$. Because of their low $\mathrm{Si} / \mathrm{Al}$ ratio $(<2), \mathrm{Ag} / \mathrm{X}$ sorbents were claimed to be not acid resistant and not applicable in the presence of high amounts of steam and $\mathrm{NO}_{\mathrm{x}}$ [3]. By contrast, Ag/MOR zeolites, which generally possess higher $\mathrm{Si} / \mathrm{Al}$ ratio, were reported to be more efficient under such conditions $[3,8,9]$. However, such studies were conducted in a different context, i.e. reprocessing of nuclear fuel, and it has also to be acknowledged that the chemical stability of $\mathrm{Ag} / \mathrm{MOR}$ zeolites comes at the cost of their cation-exchange capacity. Hence, the amount of adsorbed iodine will be limited using these adsorbents.

Overall, scientific gaps persist about the possible implementation of zeolitic materials for severe accident applications. No systematic study was carried out in order to address the effects of important zeolitic parameters on iodine retention. For instance, no attempt were made to examine the respective influences of the silver content and speciation, the $\mathrm{Si} / \mathrm{Al}$ ratio, the pore size and connectivity on iodine adsorption characteristics and diffusional properties. In this work, we aimed to bridge this gap by reporting on the chemical and structural parameters influencing the $\mathrm{CH}_{3} \mathrm{I}$ sorption performances onto silver zeolites with different structural types (FAU ( $\mathrm{X}$ and $\mathrm{Y}$ ), MFI, MOR, FER, *BEA). In the first part of the paper, 
characterization of the ion-exchanged materials was achieved by different techniques (XRD, $\mathrm{N}_{2}$-porosimetry, DRS-UV-Vis...) in order to establish afterwards structure-activity relationships with retention properties. In the second part, adsorption capacities at breakthrough and saturation, as determined from the quantitative exploitation of $\mathrm{CH}_{3} \mathrm{I}$ breakthrough experiments at $100^{\circ} \mathrm{C}$, are discussed. Since they could affect the storage stability, diffusional constraints will also be considered. After-test characterization was also performed in order to give additional insights onto the trapping mechanism.

\section{Experimental part}

\subsection{Materials}

Commercial zeolites of structural types FAU (Y, Si/Al=2.5, CBV 300), MOR ( $\mathrm{Si} / \mathrm{Al}=10$, $C B V 21 A)$, FER $(\mathrm{Si} / \mathrm{Al}=10.5, C P 914 C), * \mathrm{BEA}\left(\mathrm{Beta}, \mathrm{Si} / \mathrm{Al}=10.1, C P 814 E^{*}\right), \mathrm{MFI}(\mathrm{ZSM}-5$, 11.5, $C B V$ 2314) were all provided by Zeolyst in ammonium form. A $13 \mathrm{X}(\mathrm{NaX})$ zeolite (Si/Al=1.2, 60-80 mesh, 20305) was supplied by Sigma Aldrich.

Various loadings of silver were introduced into the different zeolitic frameworks by means of ion exchange with silver nitrate (Sigma-Aldrich, purity > $99.9 \%$ ). Exchange reactions were carried out using $200 \mathrm{~mL}$ of a $0.01 \mathrm{M}$ silver nitrate solution. $2 \mathrm{~g}$ of zeolites were added to this solution at $25{ }^{\circ} \mathrm{C}$ and stirred for 24 hours. Then, the exchanged-zeolites were vacuum-filtered and dried at $80^{\circ} \mathrm{C}$ overnight. Whenever necessary, this ion-exchange procedure was repeated up to 2 (MOR) or 3 times (Y, ZSM-5, and $13 \mathrm{X}$ ) in order to achieve higher exchange degrees and Ag contents. Prior to adsorption and characterization studies, all the zeolitic materials were calcined under air in a muffle furnace with a heating rate of $5^{\circ} \mathrm{C} / \mathrm{min}$ from room temperature to $200^{\circ} \mathrm{C}$ (plateau of 1 hour) and then to $500^{\circ} \mathrm{C}$ (plateau of 2 hours). In order to avoid any photo-reduction of silver species, all preparation steps and samples storage were 
done in the dark. Obtained zeolitic samples were denoted as $x A g /$ Structure ( $\mathrm{Si} / \mathrm{Al}$ ) where $\mathrm{x}$ is the mass percentage in silver.

A“benchmark" Ag/13X zeolite $\left(\mathrm{Si} / \mathrm{Al}=1.2,382280, \mathrm{Ag}_{84} \mathrm{Na}_{2}\left[\left(\mathrm{AlO}_{2}\right)_{86}\left(\mathrm{SiO}_{2}\right)_{106}\right] \cdot \mathrm{xH}_{2} \mathrm{O}\right)$ with $35 \mathrm{wt} \%$ silver was purchased from Sigma-Aldrich for comparison purposes. This zeolite was denoted thereafter $35 \mathrm{Ag} / 13 \mathrm{X}_{\text {comm }}(1.2)$.

\subsection{Physicochemical characterizations}

Elemental ICP analyses ( $\mathrm{Ag}, \mathrm{Na}, \mathrm{Al}$ and $\mathrm{Si}$ ) were performed at the Service Central d'Analyses of the CNRS and at the Service d'Analyses des Roches et des Minéraux (France). Measurements of the content of each element were performed using two-times ICP analyses. The uncertainty in the determination of each element was certified to be about $2 \%$ of its value (in wt\%), except for elements whose concentration is close to the detection limit $(<0.05 \%)$.

ATR infrared spectroscopy was used in order to measure the percentage of exchanged ammonium ions with silver. The different measurements were carried out using Bruker Alpha spectrometer equipped with Alpha P ATR accessory and diamond crystal. ATR-IR spectra were collected between 400 and $4000 \mathrm{~cm}^{-1}$ with a resolution of $4 \mathrm{~cm}^{-1}$ and 32 scans. Then, areas related to specific vibration modes of $\mathrm{NH}_{4}^{+}$(around $1450 \mathrm{~cm}^{-1}$ ) were quantified before and after the different ion-exchanges with silver.

Powder X-ray diffraction (PXRD) measurements before and after test were carried out using a Rigaku-Miniflex II (Japan) with the CuK $\alpha$ radiation $(\lambda=0.15418 \mathrm{~nm})$. PXRD patterns were recorded between 5 and $70^{\circ}(2 \theta)$ using increments of $0.02^{\circ}$ and a counting time of $2 \mathrm{~s}$. The mean size of $\mathrm{AgI}$ particles detected by $\mathrm{XRD}$ after $\mathrm{Ag}$-zeolites exposure to $\mathrm{CH}_{3} \mathrm{I}$ was calculated using the Debye and Sherrer Equation [10]:

$$
\mathrm{D}_{\mathrm{AgI}}=\frac{\mathrm{K} \times \lambda}{\cos \theta \times \sqrt{\mathrm{L}^{2}-\mathrm{L}_{\text {inst }}^{2}}}
$$


Where $\mathrm{D}_{\mathrm{AgI}}$ is the mean size of $\mathrm{AgI}$ crystallites $(\mathrm{nm}), \mathrm{K}$ is a dimensionless shape factor (equal to 0.9$), \lambda$ is the $\mathrm{X}$-ray wavelength $(0.15418 \mathrm{~nm}), \theta$ is the Bragg angle ( $\mathrm{rad}), \mathrm{L}$ is the full width at half maximum (FWHM) of the diffraction peak (rad) and $\mathrm{L}_{\mathrm{inst}}$ the instrumental line $\operatorname{broadening}\left(0.07^{\circ}=0.0012 \mathrm{rad}\right)$.

Porosimetric properties were determined from $\mathrm{N}_{2}$ adsorption isotherms recorded at $-196^{\circ} \mathrm{C}$ on an automated Autosorb IQ sorptiometer supplied by Quantachrome. Prior to each adsorption measurement, samples were outgassed in situ in vacuum at $80^{\circ} \mathrm{C}$ for $1 \mathrm{~h}$ and then at $350{ }^{\circ} \mathrm{C}$ for 6h to remove most of adsorbed impurities. Specific surface areas $\left(\mathrm{S}_{\mathrm{BET}}\right)$ were determined using the BET equation $\left(0.05<\mathrm{P} / \mathrm{P}_{0}<0.35\right)$. Microporous volume $\left(\mathrm{V}_{\text {micro }}\right)$ was calculated according to the $t$-plot method [11]. The total pore volume $\left(\mathrm{V}_{\text {pore }}\right)$ was measured from $\mathrm{N}_{2}$ adsorption isotherms at $\mathrm{P} / \mathrm{P}_{0}=0.97$ whereas the mesopore volume $\left(\mathrm{V}_{\text {meso }}\right)$ was deduced by the difference: $\mathrm{V}_{\text {meso }}=\mathrm{V}_{\text {pore }}-\mathrm{V}_{\text {micro }}$.

Transmission electron microscopies studies and EDS analysis were performed on a FEI Tecnai G220 microscope. Powdered samples were deposited on a copper grid coated with an amorphous carbon film using a "dry method", similar to the one described by Sayah et al. [12]. The grid was contacted with the powder then gently shaken in order to remove excess powder from the carbon film. This deposition method was used instead of the classical one (wet method using ethanol as solvent) in order to avoid any reduction of silver species [12].

DRS UV-Vis spectra were collected on a Varian Cary 4000 UV-Vis spectrometer equipped with a double monochromator and DRA900 integrating sphere. Spectra were registered between 200 and $800 \mathrm{~nm}$, with a resolution of $2 \mathrm{~nm}$ and a scan rate of $600 \mathrm{~nm} / \mathrm{min}$. Reflectance spectra were plotted in pseudo-absorbance mode, after correction with a Spectralon standard (taken as reference).

\subsection{Description of gas-phase dynamic sorption tests}


The adsorption behaviour of silver-exchanged zeolites towards $\mathrm{CH}_{3} \mathrm{I}$ was studied using dedicated breakthrough experiments. Adsorption tests were performed under dry conditions (Argon) in a fixed-bed reactor (tubular Carbolite MTF furnace with Eurotherm controller), using a sample mass of $200 \mathrm{mg}$ (placed into a quartz tube), and a total flow rate of 150 $\mathrm{mL} / \mathrm{min}$ (which corresponds to a GHSV of $20000 \mathrm{~h}^{-1}$ ). Prior to adsorption tests, a pretreatment was performed in situ. The temperature program consisted in thermally treating the zeolitic sorbents under $\mathrm{Ar}$ (Air Liquid, $99.99 \%, 60 \mathrm{~mL} / \mathrm{min})$ from $25{ }^{\circ} \mathrm{C}$ to $200{ }^{\circ} \mathrm{C}(30 \mathrm{~min}$ dwell) with a heating rate of $5{ }^{\circ} \mathrm{C} \cdot \mathrm{min}^{-1}$, followed by another heating step from 200 to $500{ }^{\circ} \mathrm{C}$ (at $5^{\circ} \mathrm{C} \cdot \mathrm{min}^{-1}, 1$ hour at $500^{\circ} \mathrm{C}$ ). Then, the temperature was cooled down under $\mathrm{Ar}$ to $100^{\circ} \mathrm{C}$ and $\mathrm{CH}_{3} \mathrm{I}$ adsorption phase was started. The $\mathrm{CH}_{3} \mathrm{I}$ concentration at the reactor inlet was set to $1333 \mathrm{ppm} / \mathrm{Ar}$ using a certified $\mathrm{CH}_{3} \mathrm{I} / \mathrm{Ar}$ bottle (Air Products, $2000 \mathrm{ppm} \pm 0.5$ ) and Brooks 5850s mass-flow controller (Ar balance). The composition of the reactor outflow was continuously monitored every 2 min using a heated FTIR gas cell (Cyclone Series -Specac, optical path length $=2 \mathrm{~m}, \mathrm{~V}=0.19 \mathrm{~L}$ ) coupled to a Varian Excalibur 4100 FTIR spectrometer with a DTGS detector. The temperature of the gas cell was maintained at $120{ }^{\circ} \mathrm{C}$ to avoid any condensation. FTIR spectra, referenced to Ar background, were recorded using a $2 \mathrm{~cm}^{-1}$ resolution and coaddition of 50 scans. For quantification purposes, a $\mathrm{CH}_{3} \mathrm{I}$ calibration curve (absorbances measured at $1263 \mathrm{~cm}^{-1}, y=2.10^{-4} x, R^{2}=0.999$ ) was validated in the range of 50-2000 ppm.

Adsorption capacities $\left(\mathrm{Q}_{\text {sat }}\right)$ at saturation were calculated from integration of $\mathrm{CH}_{3} \mathrm{I}$ breakthrough curves through the following equation (Eq. (2)):

$Q_{\text {sat }}=\frac{\mathrm{D} \times \int_{\mathrm{ti}}^{\mathrm{t}_{\mathrm{f}}}\left(\left[\mathrm{CH}_{3} \mathrm{I}\right]_{\mathrm{in}}-\left[\mathrm{CH}_{3} \mathrm{I}\right]_{\text {out }}\right) \mathrm{dt}}{\mathrm{m}}$

Where:

- $\quad \mathrm{D}$ is the total flow rate $\left(\mathrm{mL} \cdot \mathrm{min}^{-1}\right)$; 
- $\quad \mathrm{m}$ is the weight of material introduced into the reactor $(\mathrm{g})$;

- $\left[\mathrm{CH}_{3} \mathrm{I}\right]_{\text {in }}$ : the gas inlet concentration (ppmv);

- $\left[\mathrm{CH}_{3} \mathrm{I}\right]_{\text {out }}$ : the gas outlet concentration (ppmv);

- $t_{\mathrm{i}}$ : the time corresponding to Ar substitution by $\mathrm{CH}_{3} \mathrm{I}(0 \mathrm{~min})$;

- $\quad$ And $t_{f}(\min )$ is the time of bed saturation $\left(C / C_{0}=1\right)$.

Adsorption capacities at breakthrough ( $\left.\mathrm{Q}_{\text {breakthrough }}\right)$ were also quantified using Eq.2, using $\mathrm{t}_{5 \%}$ (corresponding to $\mathrm{C} / \mathrm{C}_{0}=0.05$ ) instead of $\mathrm{t}_{\mathrm{f}}$.

\section{Results and discussion}

\subsection{Characterization of silver-exchanged zeolites}

\subsubsection{Chemical properties from elemental analyses}

The most important chemical characteristics of the different silver zeolites are given in Table 1. All data were obtained from elemental analyses except the percentage of exchanged ammonium, which was determined by IR spectroscopy.

According to their initial sodium content, the investigated parent zeolites i.e. before ion exchange, could be classified in two categories:

(i) A first family of materials with a very low amount of sodium according to the supplier (Zeolyst) data. This class includes $\mathrm{MOR}\left(C B V 21 \mathrm{~A} ; \% \mathrm{Na}_{2} \mathrm{O}=0.08 \%\right)$, FER $\left(C P 914 C, \% \mathrm{Na}_{2} \mathrm{O}=0.05 \%\right)$, MFI $\left(C B V 2314, \% \mathrm{Na}_{2} \mathrm{O}=0.05 \%\right)$ and *BEA $\left(C P 814 E^{*}, \% \mathrm{Na}_{2} \mathrm{O}=0.05 \%\right)$ zeolites. Additional elemental analyses indicate the presence of titanium $(0.27 \% \mathrm{wt})$, iron $(0.08 \% \mathrm{wt})$ and calcium $(0.02 \% \mathrm{wt})$ in mordenite zeolite.

(ii) The second category is composed by $\mathrm{X}$ and $\mathrm{Y}$ faujasite zeolites, having initially a much higher sodium content. The parent $\mathrm{Na} / \mathrm{X}$ zeolite (13X supplied by SigmaAldrich, 20305) contains about $10 \mathrm{wt} \%$ sodium and various residual cations such 
as magnesium $(1.75 \mathrm{wt} \%)$, iron $(0.9 \mathrm{wt} \%)$, calcium $(0.57 \mathrm{wt} \%)$, potassium $(0.36$ wt $\%)$, titanium $(0.19 \mathrm{wt} \%)$, phosphorus $(0.08 \mathrm{wt} \%)$ and manganese $(0.015 \mathrm{wt} \%)$. On the other hand, about $1.48 \mathrm{wt} \%$ of sodium was found to be present within the parent $\mathrm{NH}_{4} / \mathrm{Y}$ zeolite $(C B V 300)$.

Consistent results with supplier data were found in terms of global Si/Al ratio. For the faujasite $\mathrm{X}$ and $\mathrm{Y}$ zeolites, it was also found that $\mathrm{Si} / \mathrm{Al}$ ratio were identical after successive ionic exchanges with silver (Table 1), which ensures that no dealumination occurred upon the employed synthesis conditions.

As expected, much higher silver amounts (> $20 \mathrm{wt} \%)$ can be achieved after several ion exchanges for $\mathrm{X}$ and $\mathrm{Y}$ faujasite zeolites in respect with the other studied structures (MOR, FER, MFI and *BEA, Ag $<10 \mathrm{wt} \%$ ). This is in line with the lower $\mathrm{Si} / \mathrm{Al}$ ratio of faujasite zeolites and their higher Cationic Exchange Capacities (CEC) [13]. Furthermore, it was reported that silver cations possess a higher affinity towards zeolitic frameworks in comparison with $\mathrm{Na}^{+}$or $\mathrm{NH}_{4}^{+}$cations [14]. Indeed, $\mathrm{Ag}^{+}$species are very polarizable and will be therefore strongly bound to anionic frameworks by electrostatic interactions [14]. Giving a same number of ionic exchanges, the $\mathrm{Ag} / \mathrm{Al}$ exchange degree depends mostly on $\mathrm{Si} / \mathrm{Al}$ ratio. For $\mathrm{Ag} / \mathrm{Y}$ zeolites, the silver exchange level increased from $0.26(\% \mathrm{Ag}=9.1 \mathrm{wt} \%)$ to 0.74 $(\% \mathrm{Ag}=22.8 \mathrm{wt} \%)$ after three successive ionic exchanges. A similar trend was obtained for $\mathrm{Ag} / \mathrm{X}$ zeolites (Table 1) although that at rather similar silver content ( 23\%), the percentage of exchange remained lower $(\mathrm{Ag} / \mathrm{Al}=0.61$ against 0.74 , Table 1$)$ remains lower due to lower $\mathrm{Si} / \mathrm{Al}$ ratio. A higher exchange level $(\mathrm{Ag} / \mathrm{Al}=0.93$, Table 1$)$ could however be estimated for the commercial $\mathrm{Ag} / \mathrm{X}$ zeolite $\left(35 \mathrm{Ag} / 13 \mathrm{X}_{\text {comm }}(1.2)\right)$.

In addition, consistent silver contents and $\mathrm{Ag} / \mathrm{Al}$ ratio (between 0.41 and 0.51 ) were obtained between our prepared Ag/MOR zeolites and those synthesized in previous works [15]. For the other zeolites (3.4Ag/BETA (10.1), 4.2Ag/FER (10.4) and 9Ag/MFI (11.5)), Ag/Al ratio 
lower than unity also indicate that exchange capacities were not reached for the studied samples.

For $\mathrm{Ag} / \mathrm{Y}$ zeolites, the percentages of exchanged ammonium (for uncalcined zeolites) increased from 58 to $73 \%$ (Table 1) after one and three repeated exchanges, respectively. Moreover, it was found that about $92 \%$ of the sodium present in parent $\mathrm{NH}_{4}-\mathrm{Y}$ (2.5) zeolite (containing $1.48 \mathrm{wt} \%$ of sodium) was meanwhile substituted by silver. These results confirm that both $\mathrm{Na}^{+}$and $\mathrm{NH}_{4}{ }^{+}$were exchanged in FAU-Y zeolites in presence of silver nitrate.

To sum up, it was shown that the amounts of exchanged silver species depend on $\mathrm{Si} / \mathrm{Al}$ ratio, on the number of successive silver exchanges and on the zeolite structure. In addition, the exchange capacity was not reached for all the studied silver-exchanged zeolites. This ensures that over-exchange, leading to silver aggregated phases on the external surface, did not occur under our synthesis conditions.

\begin{tabular}{|c|c|c|c|c|c|c|c|c|}
\hline \multirow{3}{*}{ Structure } & \multirow{3}{*}{ Name } & \multirow{3}{*}{$\mathbf{N}_{\text {IE }}^{*}$} & \multirow{3}{*}{$\begin{array}{c}\text { Measured } \\
\text { Si/Al }\end{array}$} & \multicolumn{5}{|c|}{$\%$ of } \\
\hline & & & & $\operatorname{Ag}($ wt. \%) & Ag/Al & exchanged & & $\mathrm{Na} / \mathrm{Al}$ \\
\hline & & & & & & $\mathbf{N H}_{4}^{+}$ & & \\
\hline \multirow{3}{*}{ MFI (3D) } & "H/MFI (11.5) & 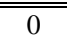 & \multirow{3}{*}{11.5} & 0.0 & 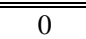 & 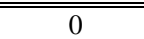 & 0.04 & 0.02 \\
\hline & $5 \mathrm{Ag} / \mathrm{MFI}(11.5)$ & 1 & & 5.0 & 0.40 & N. D & $<0.04$ & $<0.02$ \\
\hline & 9Ag/MFI (11.5) & 3 & & 9.0 & 0.72 & 78 & $<0.04$ & $<0.02$ \\
\hline \multirow{8}{*}{$\begin{array}{c}\text { Faujasite } \\
\text { (3D) }\end{array}$} & "H/Y (2.5) & 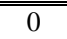 & 2.5 & 0.0 & 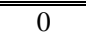 & 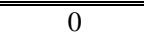 & 1.48 & 0.19 \\
\hline & $9.1 \mathrm{Ag} / \mathrm{Y}(2.5)$ & 1 & 2.4 & 9.1 & 0.26 & 58 & N. D & N. D \\
\hline & $16.8 \mathrm{Ag} / \mathrm{Y}(2.5)$ & 2 & 2.6 & 16.8 & 0.54 & 67 & N. D & N. D \\
\hline & $22.8 \mathrm{Ag} / \mathrm{Y}(2.5)$ & 3 & 2.4 & 22.8 & 0.74 & 73 & 0.12 & 0.02 \\
\hline & $13 \mathrm{X}(1.2)(\mathrm{NaX})$ & 0 & 1.2 & 0 & 0 & l & 9.97 & 0.85 \\
\hline & $7.3 \mathrm{Ag} / 13 \mathrm{X}(1.2)$ & 1 & 1.3 & 7.3 & 0.17 & l & 5.86 & 0.63 \\
\hline & $23.4 \mathrm{Ag} / 13 \mathrm{X}(1.2)$ & 3 & 1.2 & 23.4 & 0.61 & l & 1.17 & 0.14 \\
\hline & $35 \mathrm{Ag} / 13 \mathrm{X}_{\mathrm{comm}}(1.2)$ & - & 1.2 & 35 & 0.93 & I & 0.55 & 0.07 \\
\hline \multirow{3}{*}{$\begin{array}{c}\text { Mordenite } \\
\text { (1D) }\end{array}$} & "H/MOR (10) & 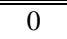 & 10 & 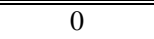 & 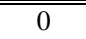 & "0 & 0.06 & 0.02 \\
\hline & 5.9Ag/MOR (10) & 1 & 10 & 5.9 & 0.40 & 35 & $<0.06$ & $<0.02$ \\
\hline & 7.3Ag/MOR (10) & 2 & 10 & 7.3 & 0.50 & 45 & $<0.06$ & $<0.02$ \\
\hline Ferrierite & " H/FER (10.4) & 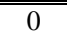 & 10.4 & 0 & / & 0 & 0.04 & 0.01 \\
\hline
\end{tabular}




\begin{tabular}{|c|c|c|c|c|c|c|c|c|}
\hline (2D) & 4.2Ag/FER (10.4) & 1 & & 4.2 & 0.30 & 35 & $<0.04$ & $<0.01$ \\
\hline \multirow{2}{*}{ *BEA (3D) } & H/BETA (10.1) & 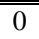 & & 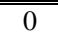 & 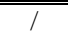 & 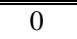 & 0.04 & 0.01 \\
\hline & 3.4Ag/BETA (10.1) & 1 & & 3.4 & 0.24 & N. D & $<0.04$ & $<0.01$ \\
\hline
\end{tabular}

* Number of ionic exchanges

Table 1 : Chemical composition of the studied silver-exchanged zeolites.

\subsubsection{Textural properties $\left(N_{2}\right.$ porosimetry at $\left.77 K\right)$}

Porous characteristics of the different investigated zeolitic materials were examined by $\mathrm{N}_{2}$ porosimetry at $77 \mathrm{~K}$. As expected, most of Ag-exchanged zeolites (isotherms not shown here) exhibited a type I isotherm typical of microporous materials [16]. In addition, *BEA zeolites presented a hysteresis loop characteristic of inter-particular mesoporosity, whose origin has to be related to specific postsynthesis treatments, for instance dealumination [17].

\begin{tabular}{|c|c|c|c|c|}
\hline Sample & $\begin{array}{c}\mathbf{S}_{\mathrm{BET}} \\
\left(\mathrm{m}^{2} / \mathrm{g}\right)\end{array}$ & $\begin{array}{c}V \text { micro } \\
\left(\mathrm{cm}^{3} / \mathrm{g}\right)\end{array}$ & $\begin{array}{l}V \text { meso } \\
\left(\mathrm{cm}^{3} / \mathrm{g}\right)\end{array}$ & $\begin{array}{l}\text { V pore } \\
\left(\mathrm{cm}^{3} / \mathrm{g}\right)\end{array}$ \\
\hline H/MFI (11.5) & 402 & 0.105 & 0.073 & 0.178 \\
\hline 5Ag/MFI (11.5) & 359 & 0.095 & 0.074 & 0.169 \\
\hline 9Ag/MFI (11.5) & 293 & 0.083 & 0.045 & 0.128 \\
\hline $\mathrm{H} / \mathrm{Y}(\mathbf{2 . 5})$ & 845 & 0.315 & 0.037 & 0.352 \\
\hline 9.1Ag/Y (2.5) & 744 & 0.277 & 0.033 & 0.310 \\
\hline $16.8 \mathrm{Ag} / \mathrm{Y}(2.5)$ & 541 & 0.202 & 0.023 & 0.225 \\
\hline 22.8Ag/Y (2.5) & 433 & 0.160 & 0.019 & 0.179 \\
\hline $13 X(1.2)(\mathrm{NaX})$ & 640 & 0.224 & 0.076 & 0.300 \\
\hline $7.3 \mathrm{Ag} / 13 \mathrm{X}(1.2)$ & 578 & 0.205 & 0.066 & 0.271 \\
\hline 23.4Ag/13X (1.2) & 472 & 0.166 & 0.059 & 0.225 \\
\hline $35 \mathrm{Ag} / 13 \mathrm{X}_{\mathrm{comm}}(1.2)$ & 369 & 0.130 & 0.045 & 0.175 \\
\hline H/MOR (10) & 529 & 0.194 & 0.026 & 0.220 \\
\hline 5.9Ag/MOR (10) & 521 & 0.185 & 0.025 & 0.210 \\
\hline 7.3Ag/MOR (10) & 486 & 0.178 & 0.022 & 0.200 \\
\hline H/FER (10.4) & 383 & 0.141 & 0.021 & 0.162 \\
\hline 4.2Ag/FER (10.4) & 357 & 0.131 & 0.020 & 0.151 \\
\hline H/BETA (10.1) & 618 & 0.180 & 0.305 & 0.485 \\
\hline 3.4Ag/BETA (10.1) & 487 & 0.142 & 0.238 & 0.380 \\
\hline
\end{tabular}

Table 2 : Textural properties of silver-exchanged zeolites from $\mathrm{N}_{2}$ porosimetry at $77 \mathrm{~K}$. 
Specific surface area $\left(\mathrm{S}_{\mathrm{BET}}\right)$, micropore volumes (V micro), mesopore volumes (V meso) and total pore volumes ( $\mathrm{V}$ pore) determined for the different zeolites from $\mathrm{N}_{2}$ adsorption/desorption isotherms at $77 \mathrm{~K}$ are gathered in Table 2. Specific surface area of the different parent zeolites ranged from $383 \mathrm{~m}^{2} / \mathrm{g}$ for H/FER (10.4) to $845 \mathrm{~m}^{2} / \mathrm{g}$ for H/Y (2.5) (Table 2). As a general rule, it appears that large-pores zeolites ( $\mathrm{H} / \mathrm{Y}(2.5), \mathrm{Na} / \mathrm{X}(1.2)$, H/BETA (10.1) and H/MOR (10)) exhibited highest specific surface area and micropore volumes. By contrast, zeolitic structures having lower pore size (composed by 8 - or 10member rings) display also lower textural data (Table 2).

After silver exchange, a decrease of these textural characteristics was noticed. Indeed, exchanged silver species partially block either the accessibility to porous network or reduce the free space within zeolite cavities. The evolution of the microporous volume $\left(\mathrm{V}_{\text {micro }}\right)$ is represented in function of the silver exchange degree $(\mathrm{Ag} / \mathrm{Al})$ on Figure 1. Higher micropore volumes were measured for large pore zeolites such as faujasite ( $\mathrm{X}$ and $\mathrm{Y}$ ) and mordenite even after repeated exchanges with silver. Obviously, the extent of that decrease becomes more significant as the exchange degree goes up. By comparing $\mathrm{X}$ and $\mathrm{Y}$ zeolites, the extent of reduction was slightly more pronounced for the $\mathrm{Ag} / \mathrm{Y}$ series, probably due to some differences existing in silver location and speciation. These aspects will be discussed with more details in the next sections. 


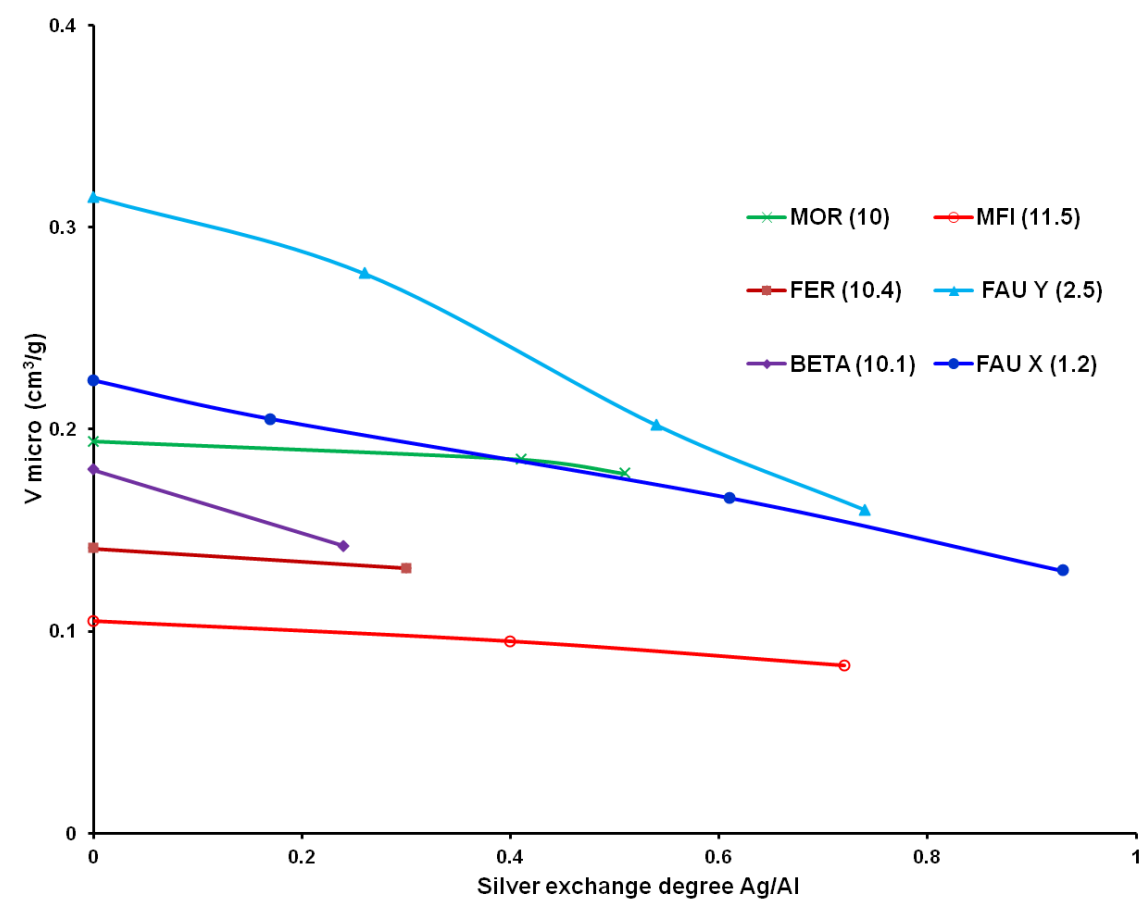

Figure 1 : Evolution of micropore volume (V micro) in function of the silver exchange degree (Ag/Al) for all investigated zeolitic materials.

\subsubsection{Structural characterization}

(i) Parent zeolites. First, the phase purity of the different parent zeolites (after calcination at $500{ }^{\circ} \mathrm{C}$ during 2 hours under air) was examined by X-Ray Diffraction. XRD patterns (Figure 2) obtained for the parent H/Y (2.5), 13X (1.2), H/MOR (10), H/BETA (10.1), H/FER (10.4) and H/MFI (11.5) zeolites were found to be similar to those reported in the literature for the different structures [18]. It is worth noting that H/BETA (10.1) zeolite is less well-crystallized than the other zeolitic structures. This is attributed to the intergrowth of several structures denoted as polymorphs A, B and C [19], which induces a poor structural order [19] (Figure 2 (C)).

(ii) Silver-exchanged faujasite zeolites. In Figure 2 (A) \& (B), no diffraction peaks typical of silver crystalline phases $\left(\mathrm{Ag}_{2} \mathrm{O}\right.$ or $\left.\mathrm{Ag}^{\circ}\right)$ were observed even at high silver exchange degrees. Hence, it confirms that most of introduced silver species are well-dispersed within the internal porous framework of faujasite zeolites, which is in line with the $\mathrm{Ag} / \mathrm{Al}$ ratio obtained from elemental analyses (Table 1). 
Nevertheless, it is interesting to note that the relative intensities of some peaks in the XRD patterns of $\mathrm{Ag} / \mathrm{X}$ and $\mathrm{Ag} / \mathrm{Y}$ zeolites were significantly changed in comparison with the parent materials (Figure 2 (A) \& (B)). Indeed, it is known that the incorporation of silver cations in zeolites induces a change in the relative electronic densities of some $h k l$ planes. This phenomenon is related to a redistribution of intrazeolite charge-compensating cations [20]. In that respect, the relative peak intensities of the (220), (311) and (331) peaks were reported to be correlated to the location of cations in faujasite structure [21,22]. Such behaviour is more pronounced for heavy elements such as silver because they scatter X-rays more strongly than the other elements present in the zeolites $(\mathrm{H}, \mathrm{Na}, \mathrm{Si}, \mathrm{Al})$. Indeed, it could be observed in [20] that for $\mathrm{Na} / \mathrm{Y}$ zeolites exchanged either with $\mathrm{Zn}^{2+}, \mathrm{Cu}^{2+}$ or $\mathrm{Ag}^{+}$cations, only silver has an obvious impact on the XRD pattern. 

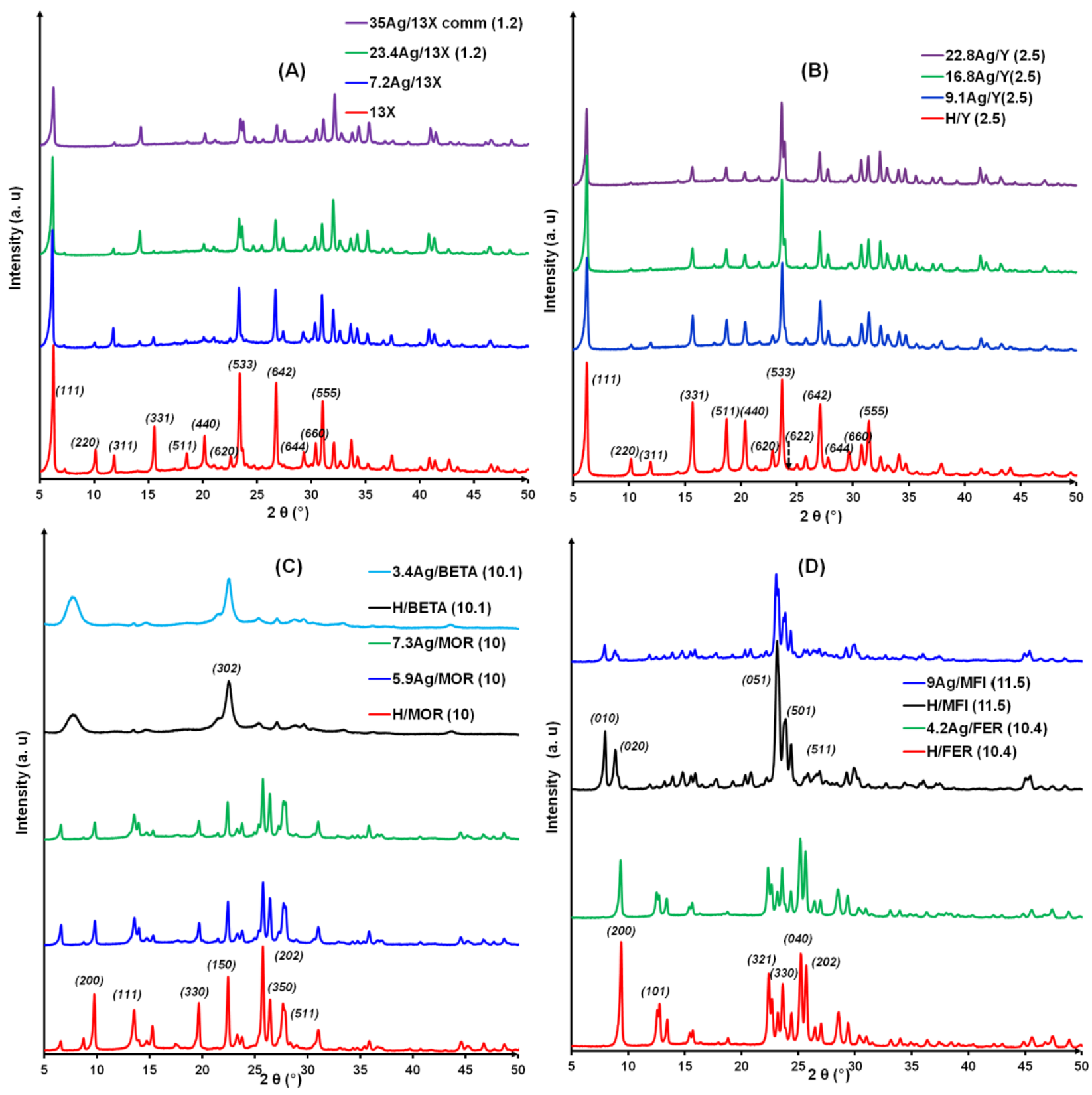

Figure 2 : X-rays diffractograms of the investigated zeolitic materials: faujasite type (X (A) \& Y (B)); other structural types (*BEA \& MOR (C), FER \& MFI (D)). Miller indexes of specific diffraction peals of parent zeolites are reported.

For the calcined parent zeolites (X \& Y, Figure 2), the order in the intensities of peaks is the following: $\mathrm{I}_{331}>\mathrm{I}_{220}>\mathrm{I}_{311}$. Following successive exchanges with silver, the order becomes: $\mathrm{I}_{331}>\mathrm{I}_{311}>\mathrm{I}_{220}\left(\right.$ Figure $2(\mathrm{~B})$ ) for $\mathrm{Ag} / \mathrm{Y}$ zeolites and $\mathrm{I}_{311}>\mathrm{I}_{220}>\mathrm{I}_{331}$ for Ag/X zeolites (Figure 2 (A)) consistently with [21] and [22], respectively. This observed differences between silver faujasite $\mathrm{X}$ and $\mathrm{Y}$ materials could be related to the presence of a higher sodium content in $\mathrm{X}$ 
zeolites (Table 1). Indeed, it was reported by Sun and Seff [23] that the presence of co-cations such as $\mathrm{Na}^{+}$may induce significant changes on both silver speciation and location. According to previous crystallographic studies [23], $\mathrm{Na}^{+}$cations may occupy preferentially sites I (D6R) and II (supercages) in $\mathrm{Ag} / \mathrm{X}$ zeolites with a low exchange degree, promoting the formation of silver clusters in sodalite cages. However, for lower sodium contents, silver species were found [23] to be preferentially located within the supercages (case of $\mathrm{Ag} / \mathrm{Y}$ zeolites and $\mathrm{Ag} / \mathrm{X}$ zeolites with high exchange degree).

(ii) Silver-exchanged zeolites - other structures. Here also, the XRD patterns of 9Ag/MFI (11.5), 4.2Ag/FER (10.4), 3.4Ag/BETA (10.1), 5.9 Ag/MOR (10) and 7.3 Ag/MOR (10) zeolites did not display any additional diffraction peaks belonging to silver crystalline phases which could be present on the external surface (Figure 2 (C) \& (D)). For Ag/MOR zeolites, a gradual decrease was observed in the relative intensity of the peak at $2 \theta=9.6^{\circ}$ corresponding to (200) planes at increasing silver content (Figure 2 (C)). This result was explained in the literature [24] by a preferential localization of silver species within the main channels (MC) of mordenite zeolite, which are parallel to (200) planes. According to previous works [25], it was shown that most of $\mathrm{Ag}^{+}$species are located within main channels and only a small fraction can be present inside the side pockets (SP). More recent theoretical investigations [26] have also confirmed these trends using energetic considerations on the stability of different exchange sites. Modification of XRD patterns related to other silver zeolites was less obvious and is not interpreted here.

\subsubsection{Silver speciation by DR-UV-Vis spectroscopy}

It was shown in many studies $[12,15,25,27]$ that DR-UV-Vis spectroscopy is useful in order to investigate the nature of silver species. The attribution of absorptions corresponding to $\mathrm{Ag}^{+}$ cations at exchange positions $\left(208-238 \mathrm{~nm}\right.$ ) and $\mathrm{Ag}^{\circ}$ nanoparticles (above $350 \mathrm{~nm}$ ) is relatively concordant between different studies [15]. However, the distinction between $\operatorname{Ag}_{n}{ }^{\delta+}$ 
( $<10$ [25]) and $\operatorname{Ag}_{\mathrm{m}}^{\circ}$ species, whose maxima were reported to be in the range of 240-350 $\mathrm{nm}$, is somewhat more difficult [15].

In $\mathrm{Ag} /$ zeolites, reduced silver can be produced from the auto-reduction of $\mathrm{Ag}^{+}$exchanged species upon calcination, even under air [28,29]. This process can be promoted in the presence of zeolite water, as depicted for instance by [23,28]:

$\left(\mathrm{Ag}^{+}-\mathrm{Z}-\mathrm{O}^{-}\right)+\mathrm{H}_{2} \mathrm{O} \rightarrow 2 \mathrm{Ag}^{\circ}+1 / 2 \mathrm{O}_{2}+2 \mathrm{Z}-\mathrm{OH}$ with $\mathrm{Z}=$ Zeolite $\quad$ Eq. (3)

Therefore, silver reduction is accompanied by regeneration of Brönsted acid sites in order to maintain the zeolite electro-neutrality. Reduced silver atoms may react with $\mathrm{Ag}^{+}$ions forming confined silver clusters $\left(\mathrm{Ag}_{\mathrm{n}}{ }^{\delta+} / \mathrm{Ag}_{\mathrm{m}}{ }^{\circ}\right)$ in zeolite cavities [30]. In order to confirm the existence of auto-reduction phenomena, it is possible to compare the DR-UV-Vis spectra of $22.8 \mathrm{Ag} / \mathrm{Y}$ (2.5) before (Figure 3 (B), blue) and after calcination (Figure 3 (B), purple). From this set of spectra, it seems clear that $\mathrm{Ag}_{\mathrm{n}}{ }^{\delta+}$ and $\mathrm{Ag}_{\mathrm{m}}^{\circ}$ clusters were produced mostly after calcination and are not present immediately after exchange/drying.

On Figure 3, are displayed the DR-UV-Vis spectra corresponding to the different silverexchanged zeolites. In all samples, $\mathrm{Ag}^{+}$ions located at exchange position coexist with charged $\mathrm{Ag}_{\mathrm{n}}{ }^{\delta+}$ and metallic $\mathrm{Ag}_{\mathrm{m}}^{\circ}$ clusters confined in the internal porosity. However, the detailed distribution of these species was found to depend both on the zeolitic structure and the silver exchange degree. 


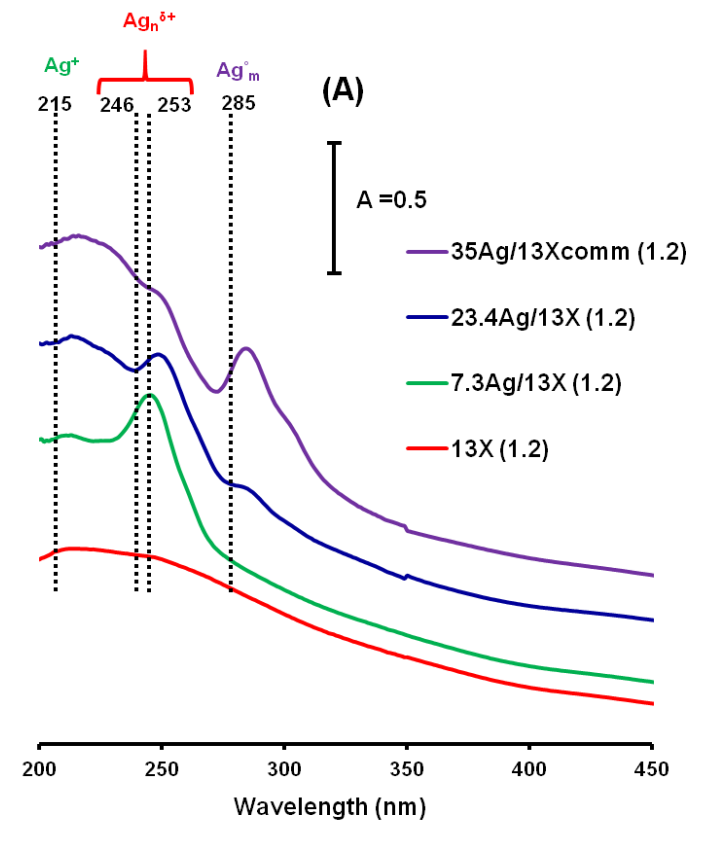

(C)

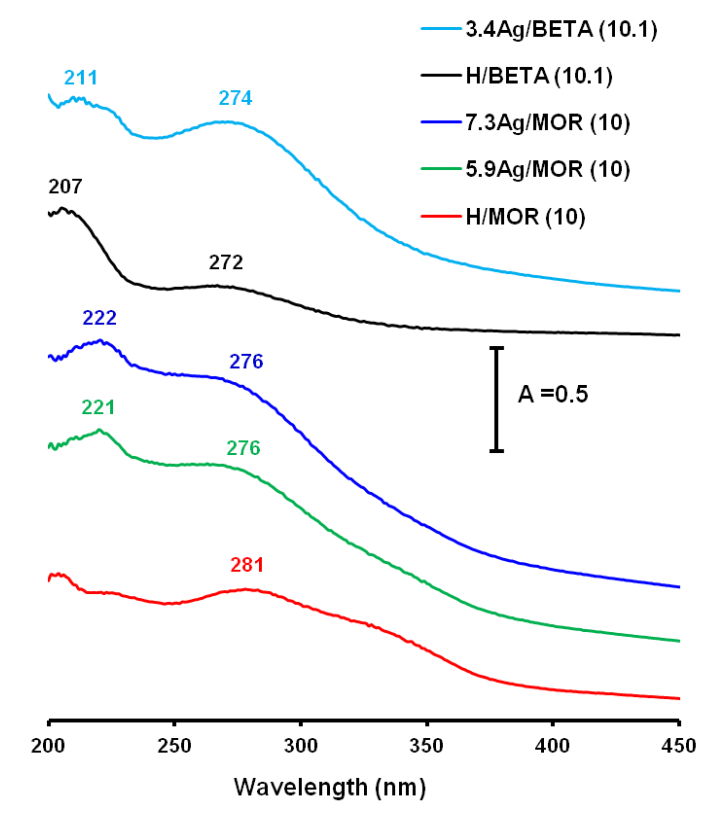

(B)

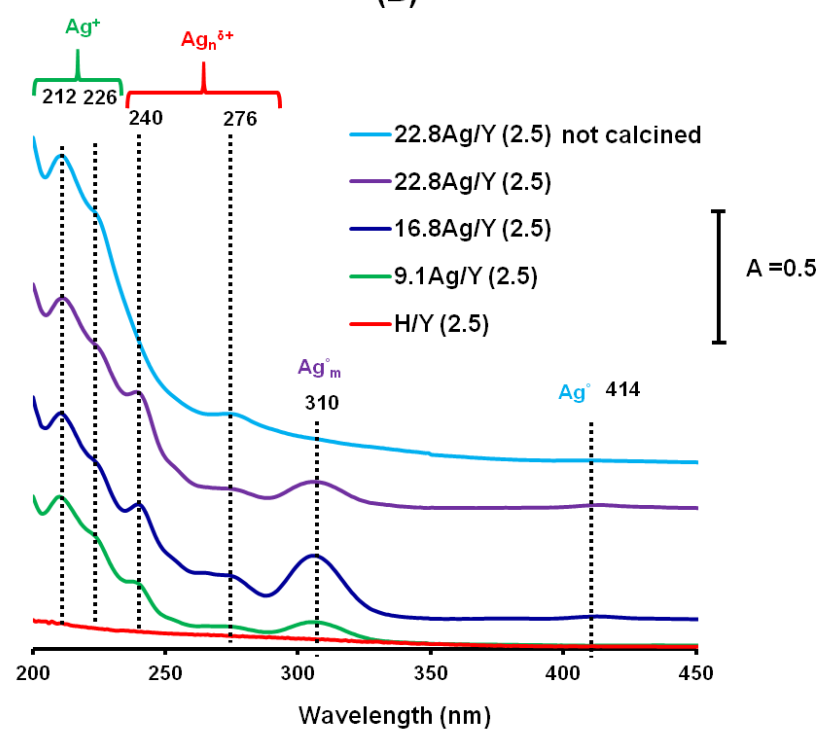

(D)

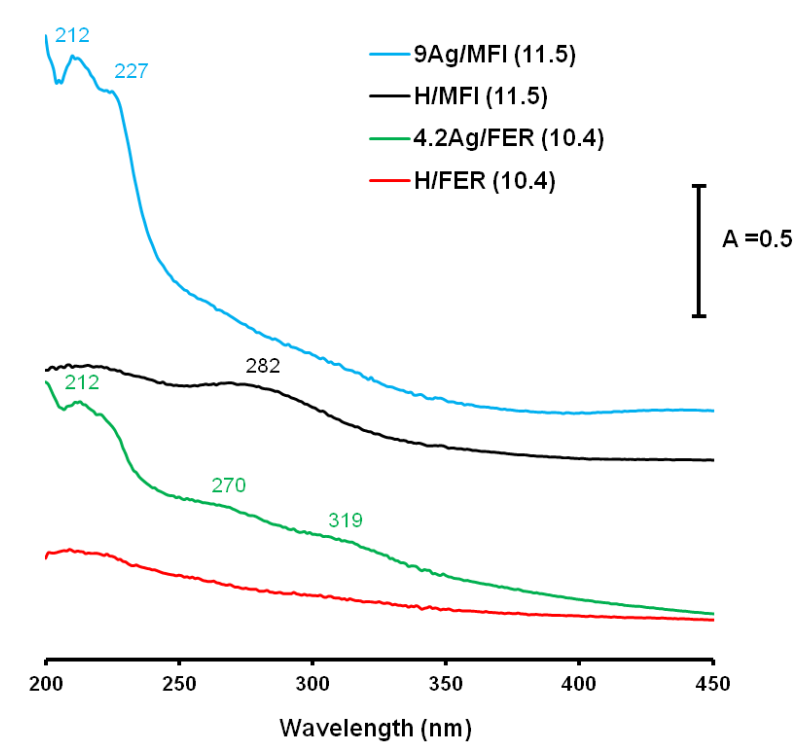

Figure 3 : DRS-UV-Vis spectra of the studied zeolites: faujasite type (X (A) \& Y (B)); other structural types (*BEA \& MOR (C), FER \& MFI (D)).

Faujasite $(X \& Y)$ type zeolites. The different behaviour, in terms of silver speciation and location of $\mathrm{Ag} / \mathrm{X}$ and $\mathrm{Ag} / \mathrm{Y}$ zeolites, which were previously inferred from XRD data, can be here depicted by examining corresponding DR-UV-Vis spectra. Overall, a better dispersion of silver species as isolated $\mathrm{Ag}^{+}$cations could be outlined for $\mathrm{Y}$ type zeolites. The strongest components at around 212 and $226 \mathrm{~nm}$ are attributed to the $4 \mathrm{~d}^{10} \rightarrow 4 \mathrm{~d}^{9} 5 \mathrm{~s}^{1}$ electron transitions 
of isolated silver cations present at two different exchange sites. For $22.8 \mathrm{Ag} / \mathrm{Y}$ (2.5), it was established in our recent study [31] by DRIFTS of adsorbed CO, that silver species were mainly located at $\mathrm{S}_{\text {II }}$ sites in faujasite structure (corresponding to a band at $2178 \mathrm{~cm}^{-1}$, Figure S1 (A) in Supplementary information ) whereas only a small fraction was present at $\mathrm{S}_{\mathrm{III}}$ sites (2195 $\mathrm{cm}^{-1}$, Figure S1 (A) in Supplementary information).

Based on the relative intensities of the different absorption bands, it seems that $\mathrm{Ag}^{+}$cations are the predominant species in the $\mathrm{Y}$ type zeolite (Figure 3 (B)). More tentatively, small components observed at around 240 and $276 \mathrm{~nm}$ on the one hand and at $310 \mathrm{~nm}$ on the other hand, are attributed respectively to small silver cationic $\mathrm{Ag}_{\mathrm{n}}{ }^{\delta+}$ of increasing size and metallic $\mathrm{Ag}_{\mathrm{m}}^{\circ}$ clusters. In addition, the apparition of broad and very small band centered at $414 \mathrm{~nm}$ can be also reported. This range of wavelengths is typical of surface plasmon resonance of silver nanoparticles $[12,25]$.

On the other hand, $\mathrm{Ag} / \mathrm{X}$ zeolites are characterized by a higher proportion of charged $\mathrm{Ag}_{\mathrm{n}}{ }^{{ }^{+}}$ $(\lambda=246$ and $253 \mathrm{~nm}$, Figure $3(\mathrm{~A}))$ and/or metallic $\mathrm{Ag}_{\mathrm{m}}^{\circ}$ clusters $(\lambda=285 \mathrm{~nm}$, Figure $3(\mathrm{~A}))$. Moreover, strong absorption tails observed in the visible region (even for the parent $13 \mathrm{X}$ zeolite), could be put in relation with the light brown color of these samples. This color seems to be in line with the presence of some fair quantities of iron oxides, as stated in section 3.1.1. Considering now the effect of the silver content, it can be seen that the silver speciation remains rather unchanged after repeated ionic exchanges for $\mathrm{Ag} / \mathrm{Y}$ zeolites. By contrast, the distribution of silver species in $\mathrm{Ag} / \mathrm{X}$ zeolites was more affected by the silver exchange degree. Indeed, the commercial silver zeolite containing about $35 \mathrm{wt} \%$ of silver $(\mathrm{Ag} / \mathrm{Al}=$ 0.93) has a larger proportion of clusters absorbing at $285 \mathrm{~nm}$, while clusters situated at 250 $\mathrm{nm}$ were the predominant species at lower silver contents (Figure $3(\mathrm{~A})$ ).

These observed differences in terms of silver speciation for $\mathrm{Y}$ and $\mathrm{X}$ faujasite materials could be related to different aspects: (i) the presence of a greater amount of hydration water in $\mathrm{X}$ 
zeolite because of its lower $\mathrm{Si} / \mathrm{Al}$ ratio: this may enhance auto-reduction phenomena and promote therefore the formation of silver clusters [28]; (ii) the presence of higher amounts of co-cations such as $\mathrm{Na}^{+}$within $\mathrm{X}$ zeolites, which may be responsible for changes in silver speciation and location as stated in the literature [23].

Other structures. First, it can be seen that rather similar absorption characteristics were observed for *BEA \& MOR (Figure $3(\mathrm{C})$ ) zeolites on the one hand and MFI \& FER materials (Figure $3(\mathrm{D})$ ) on the other hand. In the case of $\mathrm{Ag} / \mathrm{MOR}$ zeolites, silver introduction leads to the appearance of a new broad band at $222 \mathrm{~nm}$, which could be assigned to $\mathrm{Ag}^{+}$ions present at exchange sites [25]. In addition, the large component observed at $276 \mathrm{~nm}$ is related to the presence of charged silver clusters [25]. Rather similar trends were observed for *BEA type zeolite (Figure $3(\mathrm{C})$ ). Indeed, it was reported that a high acidity may promote the stabilization of small charged clusters [27].

On the other hand, 4.2Ag/FER (10.4) and 9Ag/MFI (11.5) are characterized by the predominance of isolated silver cations $(\lambda=212-227 \mathrm{~nm}$, Figure 3 (D) (corresponding to a band centered at $2192 \mathrm{~cm}^{-1}$ in FTIR spectra of adsorbed CO frequency (Figure S1 (B) in Supplementary information). Besides, a very low amount of charged and metallic silver clusters is observed (Figure 3 (D)). Therefore, phenomena leading to the growth and formation of such clusters seem to be limited within small or medium-pore zeolites namely FER $(3.5 \times 4.8 \AA ; 4.2 \times 5.4 \AA)$ and MFI (5.1 x $5.5 \AA$ 5.3 x $5.6 \AA)$. By contrast, their formation should be more promoted for large-pore zeolites such as FAU (7.4 x 7.4 $\AA$ ), *BEA (5.6 x $5.6 \AA$; 6.6 x $6.7 \AA$ ) and MOR (7.0 x $6.5 \AA$ ). These observations are in a good agreement with literature data [32], indicating that the extent of silver clusters growth inside confined media such as zeolites, is mainly limited by the size of cavities.

In conclusion, DR-UV-Vis characterization has revealed that silver species are well-dispersed as isolated cations as well as charged or metallic clusters confined in the internal structure. 
Moreover, the relative distribution of these species is dependent on various zeolitic parameters such as the pore size and pore topology, the $\mathrm{Si} / \mathrm{Al}$ ratio, the silver content and also probably the acid strength, in agreement with [33].

\subsection{Adsorption of $\mathrm{CH}_{3} \mathrm{I}$ by the different silver zeolites at $\mathrm{T}=100^{\circ} \mathrm{C}$}

\subsubsection{Quantitative exploitation of breakthrough curves}

Before starting the adsorption phase, an in situ pretreatment of silver zeolites (200 mg) was performed in argon at $500^{\circ} \mathrm{C}$ (1 hour). Then, the sorbent bed was cooled down to $100^{\circ} \mathrm{C}$ and submitted to a stream of diluted methyl iodide $\left(\left[\mathrm{CH}_{3} \mathrm{I}\right]_{0}=1333 \mathrm{ppm}, 150 \mathrm{~mL} / \mathrm{min}\right)$. The corresponding breakthrough curves are displayed in Figure 4 (A), (B) and (C). The obtained profiles differ by some parameters such as the time required for breakthrough $\left(\mathrm{t}_{5 \%}\right.$ defined by $\left.\mathrm{C} / \mathrm{C}_{0}=0.05\right)$ and the steepness of $\mathrm{C} / \mathrm{C}_{0}$ profiles after breakthrough. Discrimination between the different zeolitic sorbents can be assessed quantitatively by comparison of adsorption capacities at breakthrough $\left(\mathrm{Q}_{\text {breakthrough }}\right.$ at $\left.\mathrm{C} / \mathrm{C}_{0}=0.05\right)$ and at saturation $\left(\mathrm{Q}_{\text {sat }}\right)$ as well as by the examination of diffusional constraints. In the context of severe nuclear accident, quantities of radiotoxic iodine species that are susceptible to be released are very low $\left(\left[\mathrm{CH}_{3} \mathrm{I}\right] \approx 0.1 \mathrm{ppm}\right.$ [5]). Hence, the adsorption capacity at saturation of the filter will never be reached. Therefore, it can be considered as more relevant to discuss filtering properties in terms of adsorption capacities at breakthrough or decontamination factors $\left(\mathrm{C}_{\mathrm{in}} / \mathrm{C}_{\mathrm{out}}\right)$. Nevertheless, adsorption capacities at bed saturation are often used in order to compare performances of various adsorbents. In the following, the latter will be discussed first whereas adsorption capacities at breakthrough and diffusional constraints will be examined afterwards.

\section{a) Adsorption capacities at saturation}

By starting with Figure 4 (A), the protonated faujasite zeolite H/Y (2.5), obtained by thermal treatment at $500^{\circ} \mathrm{C}$ of the parent zeolite in ammonium form, displayed a very low adsorption 
capacity towards $\mathrm{CH}_{3} \mathrm{I}\left(\mathrm{Q}_{\text {sat }}=7 \mathrm{mg} / \mathrm{g}\right.$; Table 3$)$. This indicates that, at the temperature we used $\left(\mathrm{T}=100^{\circ} \mathrm{C}\right)$, interactions between the acid sites of $\mathrm{H} / \mathrm{Y}$ and $\mathrm{CH}_{3} \mathrm{I}$ do not really take place. This poor uptake can be also related to the lower acid strength of $\mathrm{H} / \mathrm{Y}$ zeolite as compared with $\mathrm{H} / \mathrm{MOR}$ or $\mathrm{H} / \mathrm{MFI}$ zeolites for example, which was quantified in our former study [17]. Indeed, works of Jaumain and $\mathrm{Su}$ [34] reported that other kinds of halomethane molecules (such as $\mathrm{CH}_{3} \mathrm{Cl}$ ) can interact with protonated zeolites via $\mathrm{H}$-bond complexes involving Brönsted acid sites (bridged Si-OH-Al groups). However, it was also reported that such complexes are stable up to $15^{\circ} \mathrm{C}$ for $\mathrm{H} / \mathrm{Y}$, while stability at higher temperatures (about $80^{\circ} \mathrm{C}$ ) was reported for more acidic zeolites such as H/MOR, H/MFI and H/BETA. By contrast, our data reported in Figure 4 and Table 3 clearly indicate that methyl iodide adsorption is promoted in presence of sodium and silver sites. For the $13 \mathrm{X}(\mathrm{NaX})$ zeolite containing about $10 \mathrm{wt} \%$ of sodium (Table 1), a $\mathrm{Q}_{\text {sat }}$ value of $92 \pm 6 \mathrm{mg} / \mathrm{g}$ is obtained. This is rather consistent with the works of Choi et al. [35] ( $\mathrm{Q}_{\text {sat }}$ about $110 \mathrm{mg} / \mathrm{g}$ at $\left.100^{\circ} \mathrm{C}\right)$.

As expected from HSAB theory [36] and the very high thermodynamic stability of silver iodide precipitate $\left(\mathrm{pK}_{\mathrm{s}}=16.08\right.$ [37]), a strong enhancement in sorption capacities is observed after successive ion exchanges with silver. Depending on the silver content (from 3.4 to 35 $\mathrm{wt} \%$ ), $\mathrm{Q}_{\text {sat }}$ values between $46 \pm 3$ and $267 \pm 16 \mathrm{mg} / \mathrm{g}$ were obtained (Table 3). Moreover, linear relationships (with however different slopes) are obtained between adsorption capacities at saturation and the silver content for $\mathrm{Ag} / \mathrm{Y}$ and $\mathrm{Ag} / \mathrm{X}$ zeolites (Figure 4 (A1) \& (B1)).

Interestingly, such relationships were never shown to the best of our knowledge. Among all the investigated sorbents, $\mathrm{Ag} / \mathrm{Y}$ and $\mathrm{Ag} / \mathrm{X}$ zeolites with more than $20 \mathrm{wt} \%$ silver display the highest adsorption performances thanks to their higher CEC (and lower Si/Al ratio) in comparison with the other investigated zeolites. A maximum of $267 \pm 16 \mathrm{mg} / \mathrm{g}$ is obtained for the commercial sorbent with $35 \mathrm{wt} \%\left(35 \mathrm{Ag} / 13 \mathrm{X}_{\mathrm{comm}}(1.2)\right)$. Nevertheless, a closer look at the 
data obtained (Figure 4, Table 3) indicates that the adsorption capacity of this sorbent is below the one expected from the linear fit in Figure 4 (B1). In that respect, silver exchanged faujasite $\mathrm{X}$ and $\mathrm{Y}$ zeolites with $23 \mathrm{wt} \%$ silver, display only slightly lower adsorption capacities $\left(\mathrm{Q}_{\mathrm{sat}}=234 \pm 14\right.$ and $223 \pm 13 \mathrm{mg} / \mathrm{g}$ respectively, Table 3$)$.

For the latter, DR-UV-Vis spectroscopy has shown that silver exist predominantly as dispersed species, namely $\mathrm{Ag}^{+}$ions located at exchange sites or as little charged clusters within the pores. By contrast, the proportion of charged and metallic clusters of higher size is greater in $35 \mathrm{Ag} / 13 \mathrm{X}_{\text {comm }}(1.2)$ zeolite. Therefore, it could be deduced that larger silver aggregates (especially those in pseudo-metallic state), are less efficient than $\mathrm{Ag}^{+}$cations in terms of $\mathrm{CH}_{3} \mathrm{I}$ capture.

The retention behaviour of $\mathrm{Ag} /$ zeolites prepared from structures different than faujasite (MFI, *BEA, MOR and FER) is also reported on Figure 4 (C1). For the corresponding samples (see Table 1), it is worth recalling that the silver content remains always below $10 \mathrm{wt} \%$ because of $\mathrm{Si} / \mathrm{Al}$ ratio higher than those of $\mathrm{X}$ and $\mathrm{Y}$ zeolites. Overall, it can be noticed that $\mathrm{Q}_{\text {sat }}$ values also increase with the silver content but the trend is more blurred compared with the two series of faujasite zeolites. At rather similar silver loading (9 wt $\%$ ), similar adsorption capacities at saturation ( $87 \pm 5$ and $85 \pm 5 \mathrm{mg} / \mathrm{g}$ ) were obtained for $9.1 \mathrm{Ag} / \mathrm{Y}(2.5)$ and 9Ag/MFI (11.5) (Table 3). However, these values are slightly below the trend obtained for Ag/FER, Ag/BETA and Ag/MOR zeolites ((Figure 4 (C1)) and also well below the sorption capacity found for Ag/X zeolite containing only $7.3 \mathrm{wt} \%$ silver $\left(\mathrm{Q}_{\mathrm{sat}}=149 \pm 9 \mathrm{mg} / \mathrm{g}\right.$, Table 3). Hence, in the range of low silver loadings, it seems clear that the mass percentage in silver is not the only parameter governing adsorbed quantities at saturation. 

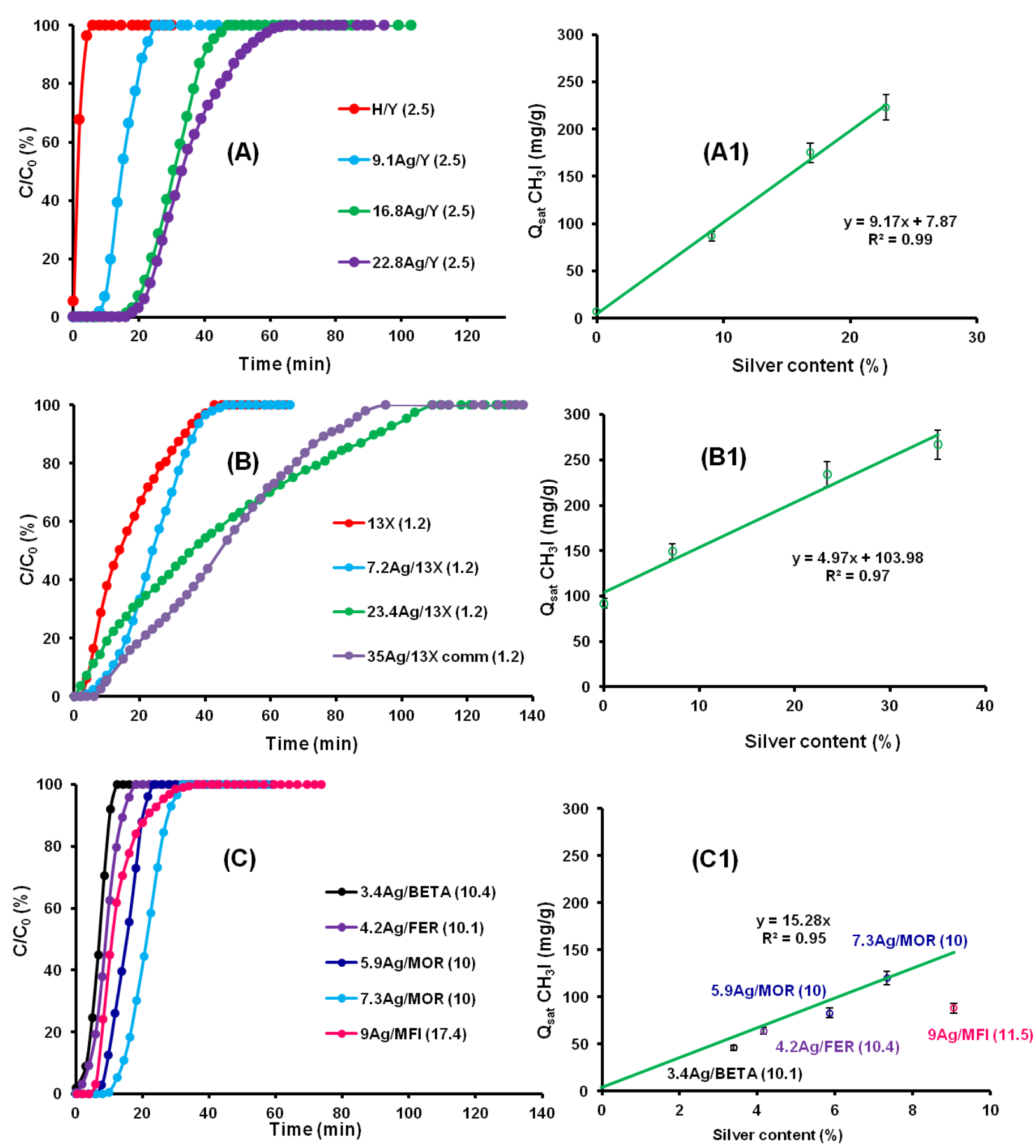

Figure $4: \mathrm{CH}_{3} \mathrm{I}$ breakthrough curves for the different studied silver zeolites (left). Linear relationships between methyl iodide adsorption capacities at saturation at $100^{\circ} \mathrm{C}$ and silver content (right). $\mathrm{Ag} / \mathrm{Y}: \mathrm{A} \& \mathrm{~A} 1, \mathrm{Ag} / 13 \mathrm{X}$ :

B\&B1, other structures: C\&C1.

This may be related to various factors. The first one can be assigned to the presence of secondary adsorption sites such as $\mathrm{Na}^{+}$ions at exchange positions. These sites are still present in significant amounts for $\mathrm{Ag} / \mathrm{X}$ zeolite prepared after a single exchange with $\mathrm{AgNO}_{3}$ $(\% \mathrm{Na}=5.9$ for $7.3 \mathrm{Ag} / \mathrm{X}(1.2)$, Table 1$)$. In addition, the presence of other residual cations, for 
instance $\mathrm{Fe}^{3+}(0.73 \mathrm{wt} \%), \mathrm{Ca}^{2+}(0.52 \mathrm{wt} \%), \mathrm{K}^{+}(0.27 \mathrm{wt} \%)$, may be also involved in $\mathrm{CH}_{3} \mathrm{I}$ retention for $\mathrm{Ag} / \mathrm{X}$ zeolites. Furthermore, steric constraints met by $\mathrm{CH}_{3} \mathrm{I}$ in microporous frameworks or partial occlusion of the pores in the course of AgI formation may alter the diffusion of methyl iodide towards some silver sites, and lower the adsorption capacity. According to the shape of the breakthrough curve, diffusional constraints may be responsible of the deviation observed in the case of $\mathrm{Ag} / \mathrm{MFI}$ zeolite (breakthrough curve in pink, Figure 4 (C)), inducing possibly a non-optimal use of silver. More insights about these aspects will be discussed later.

\begin{tabular}{|c|c|c|c|c|}
\hline Sample & $Q_{\text {sat }}(\mathrm{mg} / \mathrm{g})$ & $Q_{\text {breakthrough }}(\mathrm{mg} / \mathrm{g})$ & $\mathbf{t}_{5 \%}(\min )$ & $\mathbf{L}_{\mathbf{T}} / \mathbf{L}$ \\
\hline $\mathrm{H} / \mathrm{Y}(\mathbf{2 . 5})$ & 7 & I & 0 & I \\
\hline $9.1 \mathrm{Ag} / \mathrm{Y}(2.5)$ & $87 \pm 5$ & $34 \pm 4$ & $9 \pm 2$ & 0.64 \\
\hline 16.8Ag/Y (2.5) & $175 \pm 10$ & $78 \pm 9$ & $19 \pm 5$ & 0.49 \\
\hline 22.8Ag/Y (2.5) & $223 \pm 13$ & $90 \pm 10$ & $20 \pm 5$ & 0.70 \\
\hline $13 X(1.2)(\mathrm{Na}-\mathrm{X})$ & $92 \pm 6$ & $6 \pm 1$ & $3 \pm 1$ & 0.92 \\
\hline 7.3Ag/13X (1.2) & $149 \pm 9$ & $9 \pm 1$ & $8 \pm 2$ & 0.81 \\
\hline 23.4Ag/13X (1.2) & $234 \pm 14$ & $6 \pm$ & $3+1$ & 0.97 \\
\hline & & & & + \\
\hline $35 \mathrm{Ag} / 13 \mathrm{X}_{\mathrm{comm}}(1.2)$ & $267 \pm 16$ & $34 \pm 4$ & $9 \pm 2$ & 0.90 \\
\hline 5.9Ag/MOR (10) & $83 \pm 5$ & $31 \pm 3$ & $8 \pm 2$ & 0.64 \\
\hline 7.3Ag/MOR (10) & $120 \pm 7$ & $44 \pm 5$ & $12 \pm 3$ & 0.61 \\
\hline 9Ag/MFI (11.5) & $85 \pm 5$ & $22 \pm 2$ & $6 \pm 2$ & 0.82 \\
\hline 4.2Ag/FER (10.4) & $64 \pm 4$ & $11 \pm 1$ & $3 \pm 1$ & 0.83 \\
\hline 3.4Ag/BETA (10.1) & $46 \pm 3$ & $18 \pm 2$ & $2 \pm 1$ & 0.84 \\
\hline
\end{tabular}

Table 3 : Retention properties of the studied zeolites towards $\mathrm{CH}_{3} \mathrm{I}\left(\left[\mathrm{CH}_{3} \mathrm{I}\right]_{0}=1333 \mathrm{ppm}, \mathrm{T}=100^{\circ} \mathrm{C}\right.$, argon flow rate $=150$ $\mathrm{mL} / \mathrm{min}$, zeolite mass $=200 \mathrm{mg}$ ).

b) Adsorption capacities at breakthrough and diffusional constraints 
For nuclear filtering applications, the $\mathrm{CH}_{3} \mathrm{I}$ adsorption capacity at breakthrough is a more important parameter than the adsorption capacity at saturation because it has to be ensured than no radiotoxic iodine is released from the sorbent bed. Owing to the very low concentrations of radiotoxic iodine $(0.1-1 \mathrm{ppm}$ [5]) potentially released in the course of a severe nuclear accident, the adsorption capacity at breakthrough may not be reached. One convenient way to assess the retention properties of the filter is to measure the evolution of the decontamination factor DF $\left(D F=\frac{\left[\mathrm{CH}_{3} I\right]_{\text {in }}}{\left[\mathrm{CH}_{3} I\right]_{\text {out }}}\right)$ with time. With the detection system (timeresolved FTIR) and conditions employed in the present study $\left(\left[\mathrm{CH}_{3} \mathrm{I}\right]_{0}=1333 \mathrm{ppm}\right.$, detection limit about $15 \mathrm{ppm}$ ), we can guarantee that DF of the order of $10^{2}$ are reached during the breakthrough period for all the tested zeolites. More accurate DF measurements will be given

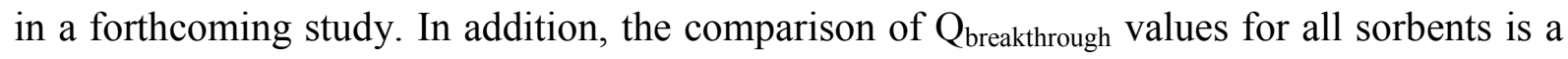
good indication of their ability of filtering. From the data reported in Table 3, it can be highlighted that $\mathrm{Ag} / \mathrm{Y}$ zeolites are by far the most efficient class of zeolitic sorbents among those investigated (Qbreakthrough values of $34 \pm 4-90 \pm 10 \mathrm{mg} / \mathrm{g}$ for silver contents in the range 9.1-22.8 wt\%, Figure 5). Here, it seems also clear that an increase in silver content is beneficial to enhance the adsorption capacity at breakthrough (Figure 5). Indeed, the presence of dispersed silver sites promotes the stable and irreversible trapping of $\mathrm{CH}_{3} \mathrm{I}$ under silver iodide precipitates, as it will be shown in the next section. 


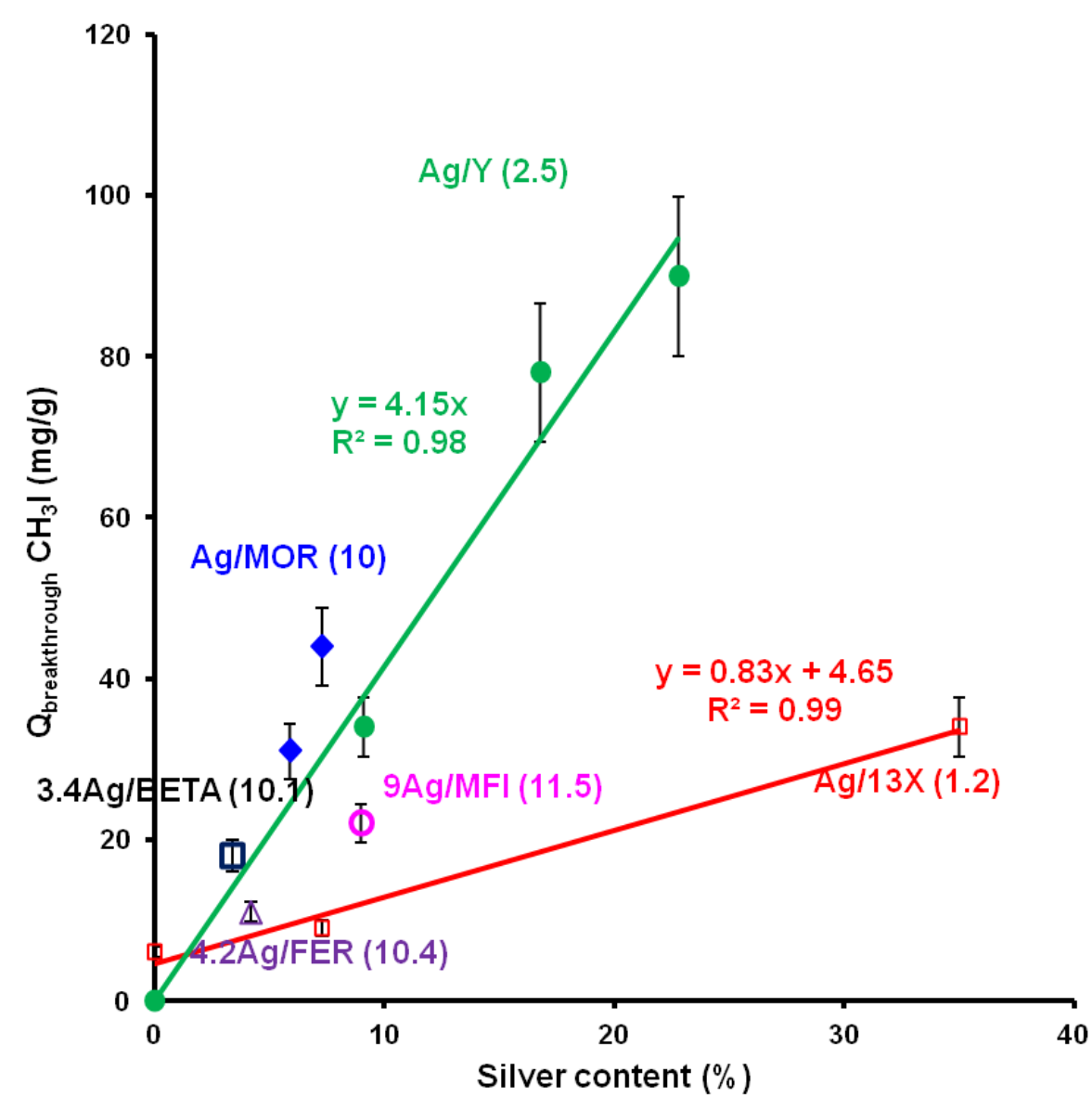

Figure 5 : Evolution of $\mathrm{CH}_{3} \mathrm{I}$ adsorption capacities at breakthrough $\left(\mathrm{Q}_{\text {breakthrough }}\right)$ in function of silver content for the studied silver-exchanged zeolites. Linear fits between $\mathrm{Q}_{\text {breakthrough }}$ and silver content are also represented for the series of $\mathrm{Ag} / \mathrm{X}$ and $\mathrm{Ag} / \mathrm{Y}$ zeolites

Despite their high adsorption capacities at saturation, comparatively poor retention properties

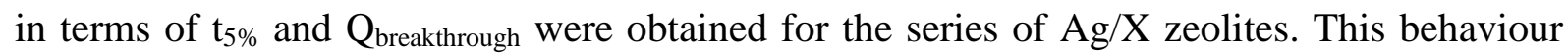
may be related to the occurrence of more significant diffusional problems for the $\mathrm{X}$ zeolites family, as shown in Figure 4 (B). On the one hand, the limitations in the intracrystalline diffusion of $\mathrm{CH}_{3} \mathrm{I}$ molecules could arise from the much higher size of cristallites for the $\mathrm{X}$ series $(0.71-5 \mu \mathrm{m})$ in comparison with the $\mathrm{Y}$ one $(0.1-0.5 \mu \mathrm{m})$, as observed by SEM imaging (not shown here). 
The adsorption behaviour of zeolites with low silver content $(<10 \mathrm{wt} \%)$ were rather different depending on the structure. First, 9Ag/MFI (11.5) (Q Q breakthrough $=22 \pm 2 \mathrm{mg} / \mathrm{g})$ zeolite displayed lower performances than $9 \mathrm{Ag} / \mathrm{Y}(2.5)$ one $\left(\mathrm{Q}_{\text {breakthrough }}=34 \pm 4 \mathrm{mg} / \mathrm{g}\right)$ despite their similar silver content. Furthermore, Ag/MOR zeolites with silver contents ranging from 5.9 to 7.3\% (Table 1) display interesting filtering properties with breakthrough sorption capacities between $31 \pm 3$ and $44 \pm 5 \mathrm{mg} / \mathrm{g}$ (Table 3, Figure 5). By contrast, poor performances were observed for 4.2Ag/FER (10.4) and 3.4Ag/BETA (10.1) ( Q breakthrough $_{\text {}} 20 \mathrm{mg} / \mathrm{g}$, Table 3) due to their very low silver content $(\mathrm{Ag} / \mathrm{Al}<0.30$, Table 1$)$. In addition, poor crystallinity of the host framework (*BEA structure) or small pore size (FER structure) can also probably invoked to explain their weak sorption properties.

The existence of diffusional constraints within the different zeolitic sorbents may be directly evaluated using the length of mass transfer zone [38]. If the latter parameter increases, this would mean that the diffusion of $\mathrm{CH}_{3} \mathrm{I}$ molecules within the internal porosity will become more restricted. Hence, the length of mass transfer zone $\left(\mathrm{L}_{\mathrm{T}}\right)$ was calculated through Eq. (4) [38]:

$\frac{\mathrm{L}_{\mathrm{T}}}{\mathrm{L}}=\frac{\mathrm{t}_{\mathrm{f}}-\mathrm{t}_{5 \%}}{\mathrm{t}_{\mathrm{f}}} \quad$ Eq. (4)

Where $t_{f}(s)$ is the total equilibrium time $\left(C / C_{0}=1\right), t_{5 \%}(s)$ is the time correspondent to $\mathrm{C} / \mathrm{C}_{0}=0.05$ and $\mathrm{L}$ is the bed length $(\mathrm{cm})$. According to this formula, it can be deduced that the parameter $\mathrm{L}_{\mathrm{T} / \mathrm{L}}$ has to be low for a more effective use of the zeolite bed.

The relationship between adsorption capacity at breakthrough ( $\left.\mathrm{Q}_{\text {breakthrough }}\right)$ and diffusionnal constraints $\left(\mathrm{L}_{\mathrm{T}} / \mathrm{L}\right)$ is depicted on Figure 6. This evolution shows a significant decrease of Q breakthrough when the diffusion becomes more severely hindered $\left(\mathrm{L}_{\mathrm{T}} / \mathrm{L}>0.7\right)$. In fact, the existence of diffusional limitations induces preferential pathways inside the zeolitic sorbent, resulting in a drastic decrease of breakthrough times and filtering properties. Among all the tested zeolites, $16.8 \mathrm{Ag} / \mathrm{Y}(2.5)$ zeolite displays the lowest diffusional constraints $\left(\mathrm{L}_{\mathrm{T}} / \mathrm{L}=0.49\right.$; 
Table 3), resulting in high breakthrough sorption capacity (about $78 \pm 9 \mathrm{mg} / \mathrm{g}$, Table 3). Hence, $\mathrm{CH}_{3} \mathrm{I}$ molecules can easily penetrate and diffuse within the internal porosity of such adsorbent. Under these conditions, the irreversible trapping of methyl iodide under the form of AgI precipitates may be enhanced, as we will see later on. Diffusional limitations may be related to several origins depending on zeolite structural and chemical properties. First, it seems clear that $\mathrm{CH}_{3} \mathrm{I}$ diffusion (kinetic diameter of 5-6 $\AA$ [9]) will be easier in large-pore zeolites $\left(\mathrm{L}_{\mathrm{T}} / \mathrm{L}<0.7\right)$, such as Ag/Y (FAU structure, 7.4 x $7.4 \AA$ ) and Ag/MOR $(7.0$ x $6.5 \AA)$, in comparison with medium or small-pore zeolites such as MFI and FER $\left(\mathrm{L}_{\mathrm{T}} / \mathrm{L}>0.8\right)$. In the latter structures, the presence of silver species or adsorbed products within the internal porosity could induce further steric constraints limiting or even hindering $\mathrm{CH}_{3} \mathrm{I}$ diffusion within the internal framework. Nevertheless, the pore size is not the only factor determining the apparent diffusion properties. As already mentioned above, zeolite crystal size is also important. The resistance to mass transfer will become much more important for micrometric crystallites (series of $\mathrm{X}$ zeolites) in comparison with nanometric ones (case of $\mathrm{Y}$ zeolites). Chemical properties (through the $\mathrm{Si} / \mathrm{Al}$ ratio) are also known to influence the hydrophilic/hydrophobic character of a given zeolite. In this work, faujasite zeolites have significantly lower $\mathrm{Si} / \mathrm{Al}$ ratio than the other structures investigated. Hence, it was not possible to completely eliminate the adsorbed water from $\mathrm{Ag} / \mathrm{Y}(\mathrm{Si} / \mathrm{Al}=2.5)$ and most noteworthy from $\mathrm{Ag} / \mathrm{X}(\mathrm{Si} / \mathrm{Al}=1.2)$ zeolites, even after an in situ pretreatment at $500^{\circ} \mathrm{C}$. The presence of water in the pores was found to catalyze the formation of oxygenated by-products from $\mathrm{CH}_{3} \mathrm{I}$, such as methanol and dimethylether [31,39], which were found in rather large amounts in $\mathrm{Ag} / \mathrm{X}$ zeolites. These by-products may possibly compete with $\mathrm{CH}_{3} \mathrm{I}$ onto the same adsorption sites (forming surface methoxy species) or form some complexes with Brönsted acid sites. This will slow down the diffusion of $\mathrm{CH}_{3} \mathrm{I}$. In our previous works dealing about multiple-hydrocarbon adsorption by different zeolitic structures, we have shown that adsorbed 
amounts and breakthrough profiles were not only influenced by the chemical nature of the adsorbates but also by the pore connectivity and topology $[17,40,41]$.

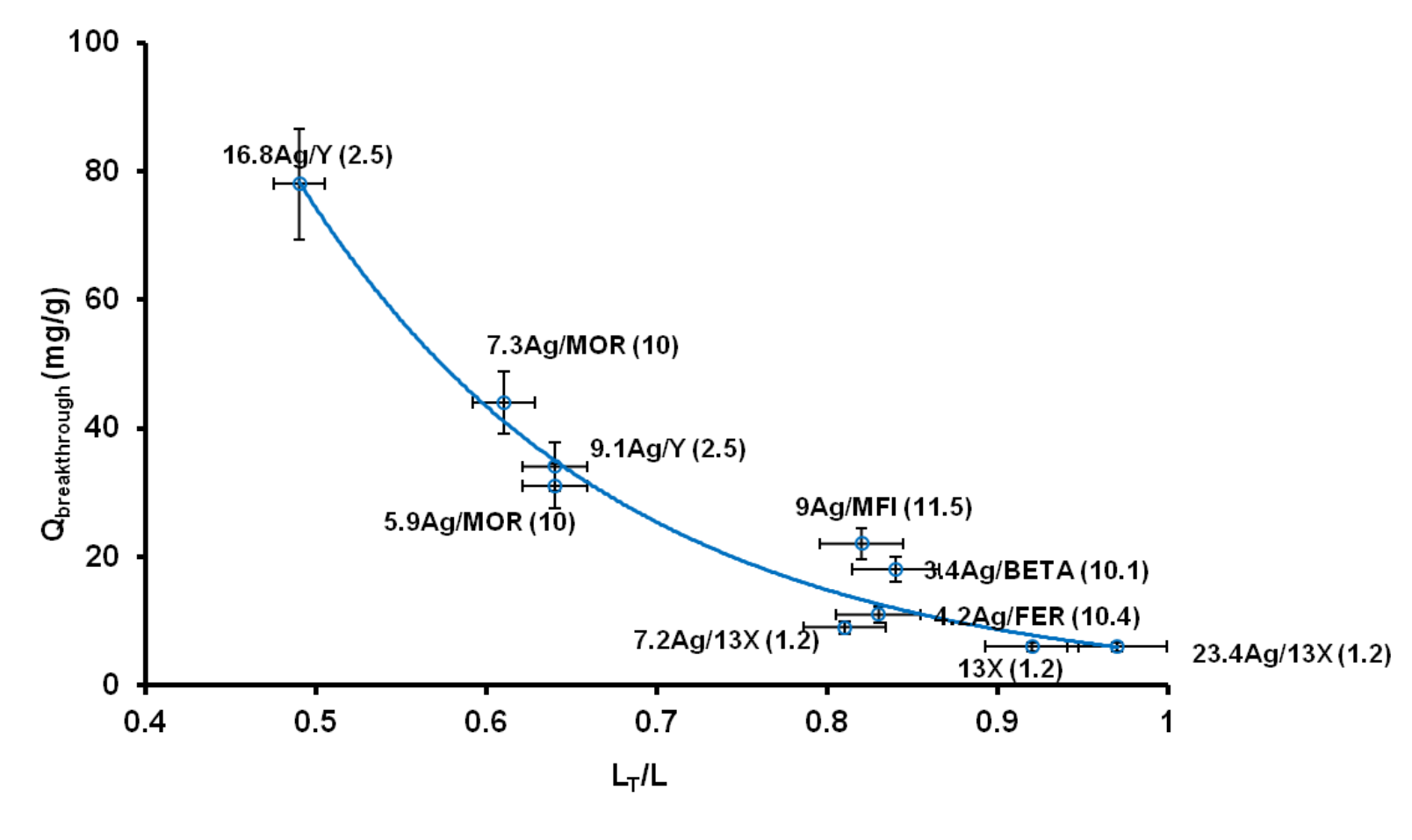

Figure 6 : Correlation between adsorption capacity at breakthrough Qbreakthrough $_{\text {and }}$ the length of mass transfer zone $\left(\mathrm{L}_{\mathrm{T}} / \mathrm{L}\right)$ for all investigated zeolites.

Finally, the presence of sodium in fauajsite zeolites appears also to adversely affect the filtering efficiency by inducing a change in the distribution or speciation of silver species (as stated in the characterization part). It is worth reminding that for $\mathrm{Ag} / \mathrm{X}$ zeolites with low to medium silver exchange levels, $\mathrm{Na}^{+}$cations will preferentially occupy the most accessible sites for adsorption (sites II in the supercage), promoting the formation of silver clusters in unexposed sodalite cages [23]. By contrast, for zeolites having lower sodium contents (the studied $\mathrm{Ag} / \mathrm{Y}$ zeolites for instance), silver species may be preferentially located within the larger supercages as $\mathrm{Ag}^{+}$cations. In that case, silver species will be more accessible to $\mathrm{CH}_{3} \mathrm{I}$ and diffusional problems will be therefore limited resulting in better retention properties. 
In the following part, a peculiar attention will be devoted to the characterization of silverexchanged zeolites after being exposed to methyl iodide at $100^{\circ} \mathrm{C}$. These ex-situ characterizations were carried out with the aim to gain insights on the mechanism of $\mathrm{CH}_{3} \mathrm{I}$ trapping by silver-exchanged zeolites.

\subsection{Physico-chemical characterizations of silver iodide species after adsorption phase}

After being saturated by $\mathrm{CH}_{3} \mathrm{I}$ at $100^{\circ} \mathrm{C}$ and following a prolonged exposition to ambient atmosphere, the different silver-exchanged zeolites, which were initially almost colorless (white) except Ag/X zeolites, became pale yellow. This colour corresponds to silver iodide (AgI, $\beta$ polymorph) [31].

$X R D$. The existence of a AgI precipitated crystalline phase was detected by XRD for most of zeolitic materials thanks to the appearance of new diffraction peaks at $2 \theta=23.7^{\circ}(111), 39.3^{\circ}$ (220) and $46.4^{\circ}$ (311) (Figure 7). Determination of the mean crystallite size by DebyeScherrer equation indicates the existence of AgI nanocristallites (size of 11, 37 and $51 \mathrm{~nm}$ for 3.4Ag/BETA (10.1), 35Ag/ $\mathrm{X}_{\text {comm }}$ (1.2) and $22.8 \mathrm{Ag} / \mathrm{Y}$ (2.5), respectively) at the external surface of silver zeolites. However, no experimental evidence for the formation of these species could be obtained from XRD for 4.2Ag/FER (10.4) and 7.3Ag/MOR (10) zeolites, presumably due to the detection limit of this technique, which cannot see very small crystallites $(<3 \mathrm{~nm})$. 


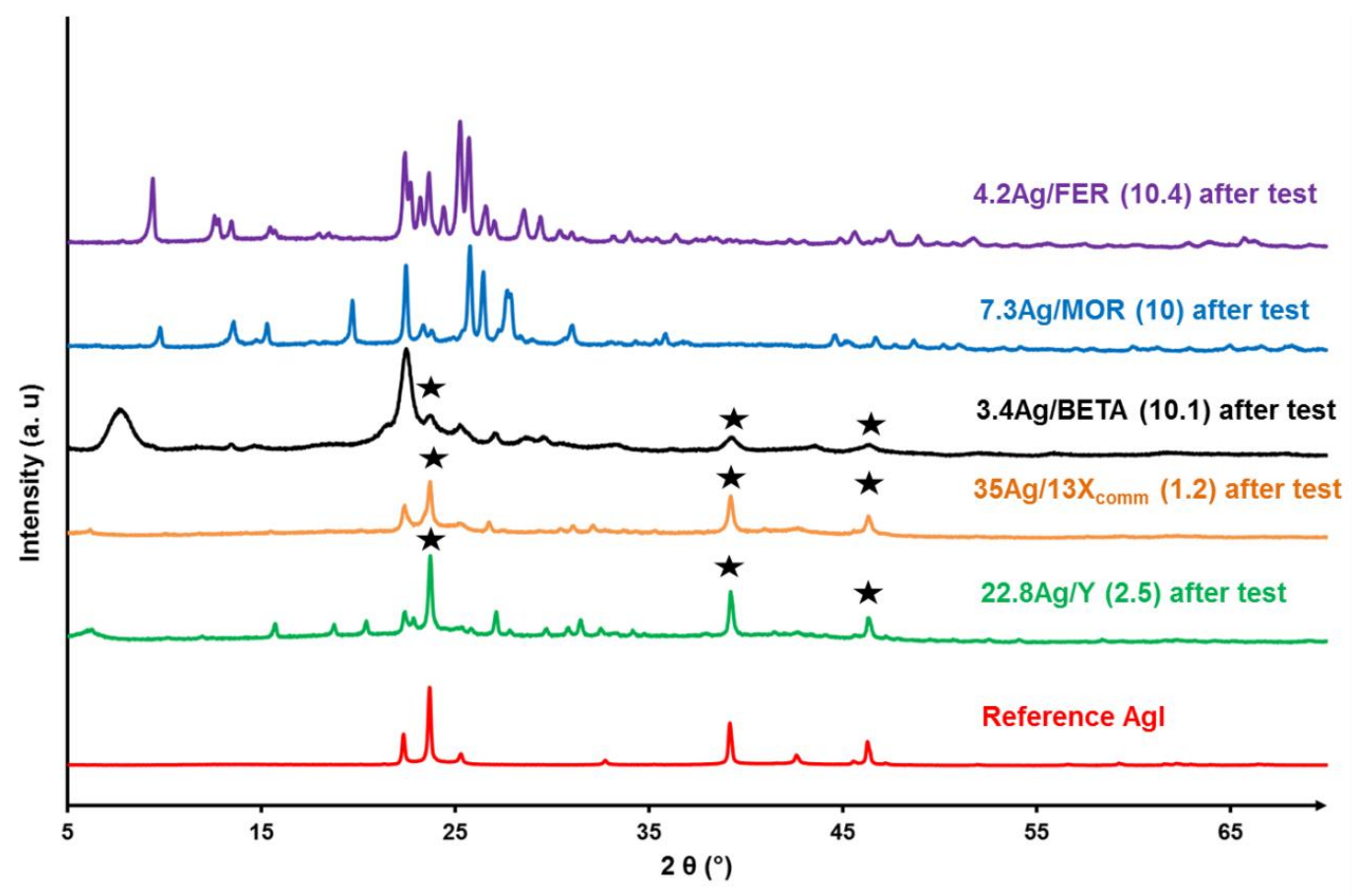

Figure 7 : Experimental illustration by XRD of $\mathrm{AgI}$ formation after exposure to $\mathrm{CH}_{3} \mathrm{I}$ for the different tested silver zeolites.

DR-UV-Vis spectroscopy. Complementary information was obtained from this technique, thanks to its better sensitivity to detect molecular or crystalline silver iodide species [42]. In the literature, the presence of characteristic absorptions in the UV region was initially assigned to the presence of evaporated $\mathrm{AgI}$ and $(\mathrm{AgI})_{\mathrm{x}}$ clusters confined in the $\alpha$ cages of LTA zeolite [42]. When studying the in situ adsorption of $\mathrm{CH}_{3} \mathrm{I}$ on $\mathrm{Ag} / \mathrm{Y}$ zeolite, a progressive blueshift of absorptions in the UV region was also observed by us due to the formation of colorless AgI entities of increasing size inside the supercages [31]. By contrast with confined AgI species, nanometric AgI cristallites on the external surface are characterized by a yellowish pale color and an absorption edge in the visible region. This was the case of all spent silver zeolites (i.e. after $\mathrm{CH}_{3} \mathrm{I}$ test) used in this study. In that respect, a commercial micrometric AgI reference (Alfa Aesar, 11419) presents an intense absorption edge at $432 \mathrm{~nm}$ (Figure 8).

In the case of $\mathrm{Ag} / \mathrm{MOR}$ and $\mathrm{Ag} / \mathrm{FER}$, absorption bands centered at 415 and $416 \mathrm{~nm}$, respectively, were observed (Figure 8). These bands can be assigned to silver iodide 
crystallites whose size is much lower than bulk AgI precipitates (probably below 2-3 nm since they were not detected by XRD).

For the other silver zeolites (Ag/13X, $\mathrm{Ag} / \mathrm{Y}$ and $\mathrm{Ag} / \mathrm{BETA})$, the absorption edge is comparatively more pronounced and shifted to slightly higher wavelengths (Figure 8). This is in good agreement with the detection of AgI phase after test by XRD. The absorption tail above $450 \mathrm{~nm}$ for $\mathrm{Ag} / \mathrm{X}$ zeolite cannot be related to $\mathrm{CH}_{3} \mathrm{I}$ capture, because it was already present before test and assigned to traces or iron oxides in the parent $\mathrm{NaX}$ zeolite (Figure 3 (A)).

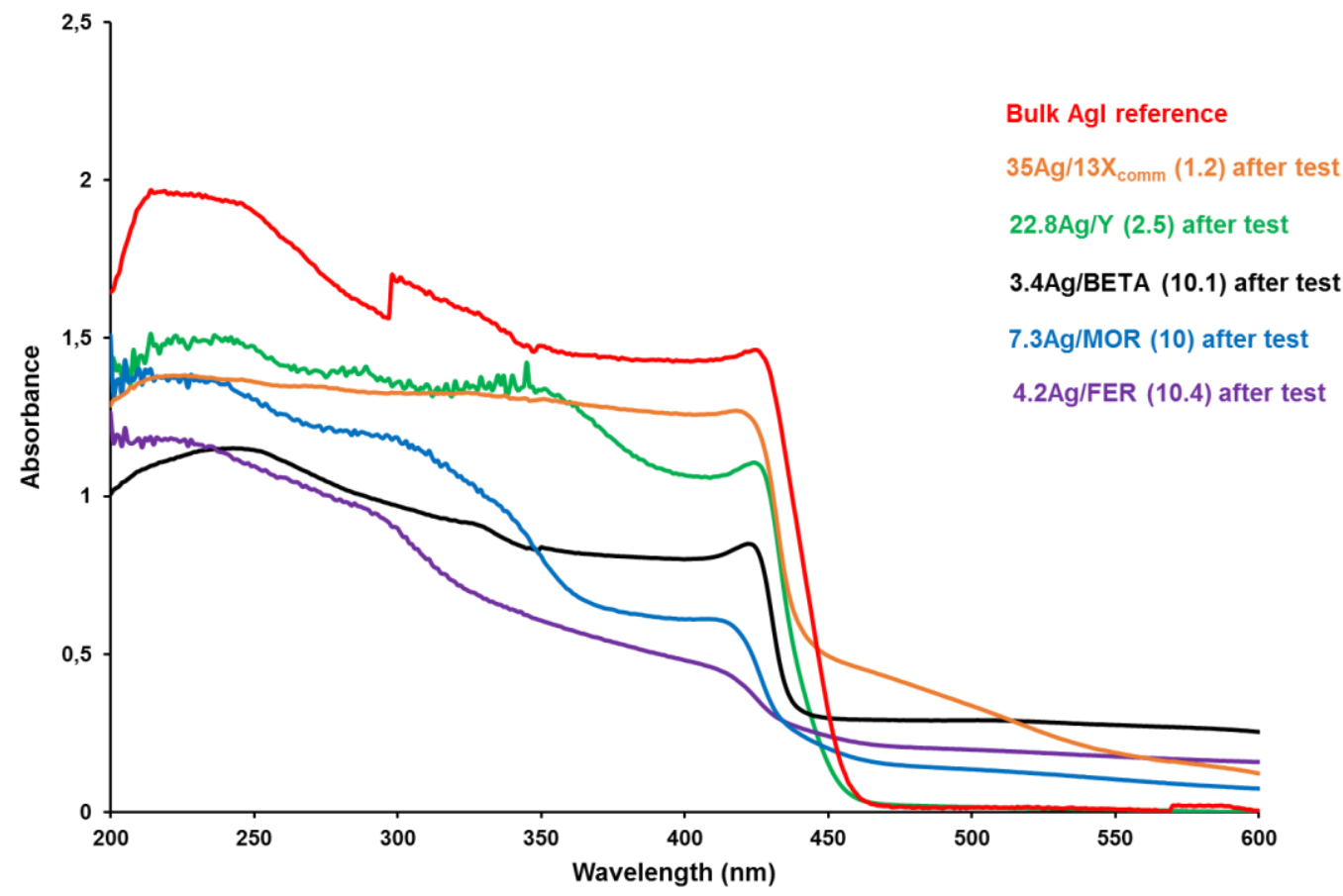

Figure 8 : DR-UV-Vis spectra of silver-exchanged zeolites after $\mathrm{CH}_{3} \mathrm{I}$ adsorption test. DR-UV-Vis spectrum of bulk reference AgI was also displayed (red curve).

Finally, a correlation between the mean particle size obtained by XRD and the wavelength of the absorption edge was attempted but was not completely successful (see Figure S2 in Supplementary information). Nevertheless, it can be concluded that DR-UV-Vis spectroscopy is useful in detecting small silver iodide entities which cannot be detected by XRD. 
TEM. Complementary data for some silver zeolites $(22.8 \mathrm{Ag} / \mathrm{Y}$ (2.5) and 7.3Ag/MOR (10)) were also obtained from Transmission Electron Microscopy (TEM). Some images collected before (A-C) and after (B-D) exposure to $\mathrm{CH}_{3} \mathrm{I}$ are presented in Figure 9.

For $22.8 \mathrm{Ag} / \mathrm{Y}$ (2.5), very small metallic silver nanoparticles (size $1-5 \mathrm{~nm}$ ), were detected instantaneously after exposure to the electronic beam (Figure 9 (A)). The formation of these particles, not detected by XRD, was confirmed by the appearance of regular crystalline fringes $\left(d_{111}=2.35 \AA\right)$ [28], as well as by EDS analysis. A prolonged exposure under the beam led to the formation of larger metallic entities (see Figure S3 in supplementary information). Although DR-UV-Vis spectra of Ag/Y zeolites have shown the existence of a small fraction of these metallic species (Figure $3(\mathrm{~B})$ ), it is believed that most of the observed particles do not exist in the original silver zeolite. In the case of $\mathrm{Ag} / \mathrm{MOR}$, aggregated forms of metallic silver (20-30 $\mathrm{nm})$ due to coalescence phenomena under the conditions in the microscope can be also observed (Figure $9(\mathrm{C})$ ).

$\mathrm{Ag} / \mathrm{Y}$ and $\mathrm{Ag} / \mathrm{MOR}$ samples after $\mathrm{CH}_{3} \mathrm{I}$ test (Figure 9 (B) and (D)) were also investigated with the aim to gain insights about the location and size of AgI entities. EDS I/Ag ratio collected at various locations (red squares) indicate that the use of silver for the capture of iodine is not homogeneous. On the one hand, I/Ag ratio close to unity can be detected in light zones of the images both for 22.8Ag/Y (2.5) and 7.3 Ag/MOR (10) zeolites (Figure 9 (b) and (d)). They may correspond to embedded AgI entities within the pores. By contrast, significantly lower I/Ag ratio (even equal sometimes to 0 ) were measured in darker zones of the samples. Here again, these zones were found to correspond to silver nanoparticles of various sizes $(5-40 \mathrm{~nm}$ for $22.8 \mathrm{Ag} / \mathrm{Y}(2.5)$, and 5-60 $\mathrm{nm}$ for $7.3 \mathrm{Ag} / \mathrm{MOR}$ (10), see for instance the inset on Figure 9 (b)). Because these $\mathrm{Ag}^{\circ}$ nanoparticles were not detected by XRD after test (Figure 7), it seems likely that they were formed from AgI entities due to the strongly reducing conditions applied in TEM measurements. Overall, this suggests that embedded AgI species in the porous matrix 
are probably less sensitive to photo-reduction phenomena than AgI aggregates, present on the external surface.
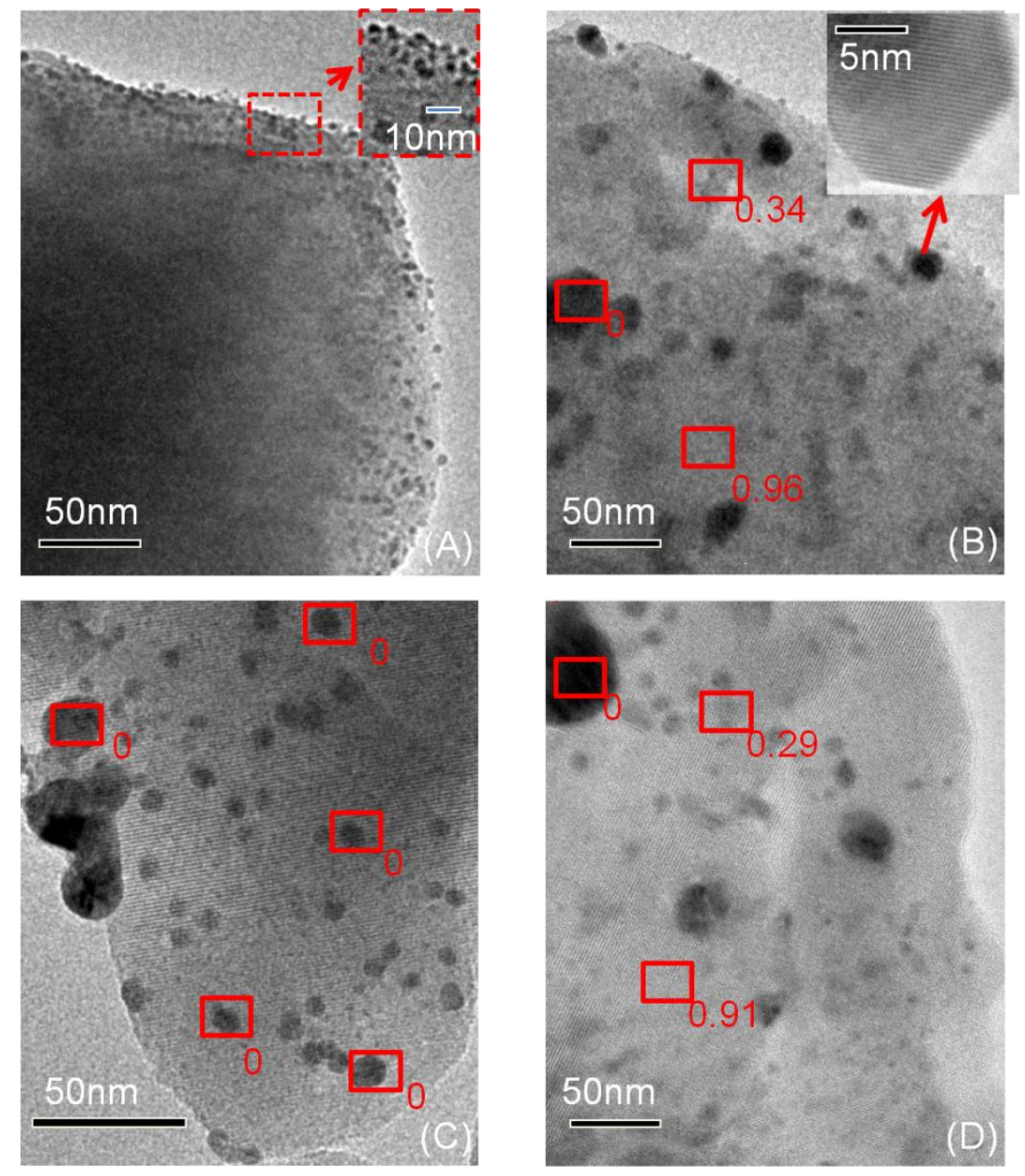

Figure 9 : TEM images of: $22.8 \mathrm{Ag} / \mathrm{Y}(2.5)$ before (A) and after $\mathrm{CH}_{3} \mathrm{I}$ adsorption (B); 7.3Ag/MOR (10) before (C) and after test (D). The red area corresponds to the EDS analysis and I/Ag ratio is indicated.

To sum up, the existence of silver iodide precipitates of different sizes after $\mathrm{CH}_{3} \mathrm{I}$ adsorption on silver-exchanged zeolites was revealed using several characterization techniques. In previous works [31,39], AgI formation was reported to occur through a precipitation reaction (Eq. (5)) between silver species and iodide $\mathrm{I}^{-}$after a first step involving the dissociation of $\mathrm{CH}_{3} \mathrm{I}$ :

$\mathrm{Ag}-\mathrm{Z}+\mathrm{CH}_{3} \mathrm{I} \rightarrow \mathrm{AgI}+\mathrm{C}$-by products with $\mathrm{Z}=$ Zeolite $\quad$ Eq. (5) 
Processes leading to the growth of AgI precipitates in the internal and external surface of zeolite cristallites were directly observed by in situ DR-UV-Vis spectroscopy in our recent study on $22.8 \mathrm{Ag} / \mathrm{Y}$ (2.5) [31]. It was found that molecular AgI and clusters of increasing size (up to $n=4$ ) are first formed exclusively within the supercages in the course of $\mathrm{CH}_{3} \mathrm{I}$ exposure. Yellowish AgI precipitates are formed later when transferring the in situ exposed zeolite to ambient conditions. In presence of humid air, some sintering occurs.

\section{Conclusions}

In this study, the chemical, textural and structural parameters responsible for the retention properties of silver zeolite sorbents towards $\mathrm{CH}_{3} \mathrm{I}$ under gas-phase dynamic conditions at $100^{\circ} \mathrm{C}$ were systematically investigated. 13 zeolitic sorbents, containing silver in the range 0 $35 \mathrm{wt} \%$ were synthesized from different parent structures (FAU X and Y, MFI, MOR, *BEA and FER) and successive ion exchanges (up to 3) with a silver nitrate solution.

The in-depth characterization of silver species in the obtained sorbents by elemental analyses, $\mathrm{N}_{2}$ porosimetry at $77 \mathrm{~K}, \mathrm{XRD}, \mathrm{DR}-\mathrm{UV}-\mathrm{V}$ is spectroscopy, TEM and DRIFTS of adsorbed CO revealed that no over-exchange took place under the employed synthesis conditions, in line with the absence of segregated $\mathrm{Ag}$ and $\mathrm{Ag}_{2} \mathrm{O}$ phases. Instead, silver species were welldispersed inside the zeolites pore systems, either as $\mathrm{Ag}^{+}$cations at exchange sites or as embedded clusters $\left(\mathrm{Ag}_{\mathrm{n}}{ }^{++}\right.$and $\left.\mathrm{Ag}_{\mathrm{m}}^{\circ}\right)$. The existence of the latter has for origin some autoreduction processes involving $\mathrm{Ag}^{+}$cations in the course of the thermal activation of the sorbents. The relative distribution of these silver cations and clusters in each sorbent was found to be dependent on the framework type, the acid strength and the exchange degree. For faujasite zeolites, this distribution was also influenced by the presence or absence of sodium as co-cations. 
From the quantitative exploitation of $\mathrm{CH}_{3} \mathrm{I}$ breakthrough curves at $100^{\circ} \mathrm{C}$ in dry atmosphere, it was established that adsorption capacities at saturation of the zeolitic bed depend mainly on silver content. Linear relationships were obtained between these two parameters for different series of zeolites and $\mathrm{Q}_{\text {sat }}$ values above $200 \mathrm{mg} / \mathrm{g}$ were reached for faujasite zeolites with more than $20 \mathrm{wt} \%$ silver. Adsorption capacities at breakthrough and related diffusional constraints were comparatively much more influenced by the nature of the framework (pore size and connectivity) and other chemical parameters (presence of sodium, $\mathrm{Si} / \mathrm{Al}$ ratio) than simply by the silver content. Among the sorbents investigated, large-pore Ag/Y with high silver content (above $15 \mathrm{wt} \%$ ) and to a lesser extent Ag/MOR zeolites displayed the best filtering properties according to the envisaged nuclear application, whereas small-to-medium pore zeolites were more subjected to diffusional limitations. In this study, problems relevant to $\mathrm{CH}_{3} \mathrm{I}$ diffusion within the faujasite pore system were much more important for $\mathrm{Ag} / \mathrm{X}$ than for $\mathrm{Ag} / \mathrm{Y}$ zeolites. This is due namely to : (i) the presence of $\mathrm{Na}^{+}$cations in partially exchanged $\mathrm{Ag} / \mathrm{X}$ zeolites, which act as secondary (and weak) adsorption sites and somewhat hinder the accessibility of methyl iodide to silver sites; (ii) the larger crystal size of $\mathrm{Ag} / \mathrm{X}$, which induced some resistance to mass transfer from the surface to the bulk.

After-test characterizations by several techniques indicate that AgI precipitated entities were formed in each silver sorbent. Owing to sintering processes occurring rapidly under ambient conditions, these species are located namely at the external surface of the crystallites, after a first step involving the $\mathrm{CH}_{3} \mathrm{I}$ dissociation and the formation of confined $\mathrm{AgI}$ species within the pores.

\section{Acknowledgments}

The research leading to these results is partly funded by the European Atomic Energy Community's (Euratom) Seventh Framework Programme FP7/2007-2013 under grant agreement $n^{\circ}$ 323217. This work has been also supported by the French State under the 
program "Investissements d'Avenir" called MIRE, managed by the National Research Agency (ANR) under grant agreement $n^{\circ}$ ANR-11-RSNR-0013-01.

\section{References}

[1] L. Cantrel, L.E. Herranz, S. Guieu, T. Albiol, R. Collet, T. Lind, T. Karkela, C. Mun, D. Jacquemain, M. Chebbi, Overview of ongoing and planned R\&D works on delayed releases and FCVS efficiencies, in : Proceedings of ICAPP 2015, Nice (France), May 03-06, 2015.

[2] B. Clément, L. Cantrel, G. Ducros, F. Funke, L. Herranz, A. Rydl, G. Weber, C. Wren, State of the Art Report on Iodine Chemistry, OCDE report, NEA/CSNI/R, 2007. /1, 2007.

[3] D.R. Haefner, T.J. Tranter, Methods of gas phase capture of iodine from fuel reprocessing off-gas: A literature survey, INL/EXT-07-12299, Idaho National Laboratory, 2007.

[4] D. Jacquemain, S. Guentay, S. Basu, M. Sonnenkalb, L. Lebel, H.-J. Allelein, B. Liebana, B. Eckardt, L. Ammirabile, Status Report on Filtered Containment Venting, OECD/NEA/CSNI, Report NEA/CSNI/R, 2014. /7, 2014.

[5] L.E. Herranz, T. Lind, K. Dieschbourg, E. Riera, S. Morandi, P. Rantanen, M. Chebbi, N. Losch, State Of The Art Report : Technical Bases for Experimentation on Source Term Mitigation Systems, Passam-Theor-T04 [D2.1], 2013.

[6] D.T. Pence, F.A. Duce, and W.J. Maeck, Developments in the Removal of Airborne Iodine Species with Metal Substituted Zeolites, in : Proceedings of the $12^{\text {th }}$ AEC Air Cleaning Conference, Tennessee (USA), August 28-31, 1972.

[7] W.J. Maeck, D.T. Pence, J.H. Keller, A Highly Efficient Inorganic Adsorber for Airborne Iodine Species (Silver Zeolites Development Studies), Idaho Nuclear Corporation, Idaho Falls, 1969. 
[8] B.A. Staples, L.P. Murphy, T.R. Thomas, Airborne elemental iodine loading capacities of metal zeolites and a dry method for recycling silver zeolites, in : Proceedings of the $14^{\text {th }}$ ERDA Air Cleaning Conference 1, 363-380, 1976.

[9] R.D. Scheele, L.L. Burger, C.L. Matsuzaki, Methyl Iodide Sorption by Reduced Silver Mordenite, PNL-4489, Pacific Northwest Laboratory, 1983.

[10] P. Scherrer, N.G.W. Gottingen, Math-Pys. Kl. 2 (1918) 96-100.

[11] C.B. Lippens, B.G. Linsen, J.H. de Boer, J. Catal. 3 (1964) 32-37.

[12] E. Sayah, D. Brouri, Y. Wu, A. Musi, P. Da Costa, P. Massiani, Appl. Catal. A: Gen. 406 (2011) 94-101.

[13] E.M. Flanigen, in: H. van Bekkum, E.M. Flanigen, J.C. Jansen (Eds.), Introduction to Zeolite Science and Practice, Studies in Surface Science and Catalysis, Stud. Surf. Sci. Catal., Elsevier, Amsterdam, 1991, p. 58.

[14] H.S. Sherry, J. Phys. Chem 70 (1966) 1158-1168.

[15] R. Bartolomeu, B. Azambre, A. Westermann, A. Fernandes, R. Bertolo, H. Issa Hamoud, C. Henriques, P. Da Costa, Appl. Catal. B: environ. 150-151 (2014) 204-217.

[16] S. Brunauer, L.S. Deming, W.S. Demming, E. Teller, J. Amer. Chem. Soc. 62 (1940) 1723.

[17] A. Westermann, B. Azambre, J. Phys. Chem. C 120(45) (2016) 25903-25914.

[18] http:// http://www.iza-online.org/.

[19] A. Corma, M. Moliner, A. Cantin, M. J. Diaz-Cabanas, J.L. Jorda, D. Zhang, J. Sun, K. Jansson, S. Howmöller, X. Zou, Chem. Mater. 20 (2008) 3218-3213.

[20] A. Zhang, T.B. Shi, C.Z. Jia, Y. Chen, M.Y. He, Appl. Catal. B: environ. 82 (2008) 1-10.

[21] L. Ferriera, A.M. Fonseca, G. Botelho, C.A. Aguiar, I.C. Neves, Microporous and Mesoporous Mater. 160 (2012) 126-132.

[22] M.S. Niasari, Polyhedron 28 (2009) 12321-2328. 
[23] T. Sun, K. Seff, Chem. Rev. 94 (2004) 857-870.

[24] C. Carolina, B.J. Carlos, B.M. L. Zapata, Z.J. Manuel, Microporous and Mesoporous Mater. 188 (2014) 118-125.

[25] S.G. Aspromonte, M. D. Mizrahi, F. A. Schneeberger, J. M. R. Lopez, and A. V. Boix, J. Phys. Chem. C 117 (2013) 25433-25442.

[26] S. Chibani, M. Chebbi, S. Lebègue, T. Bucko, M. Badawi, J. Chem. Phys 144 (2016) 244705-1 - 244705-10.

[27] J. Shibata, Y. Takada, A. Shichi, S. Satokawa, A. Satsuma, T. Hattori, Appl. Catal. B: Env. 54 (2004) 137-144.

[28] M.D. Baker, G.A. Ozin, J. Godber, J. Phys. Chem. 89 (1985) 305.

[29] E. Sayah, D. Brouri, P. Massiani, Catal. Today 218-219 (2013) 10-17.

[30] S.M. Kanan, M.C. Kanan, H.H. Patterson, Res. Chem. Intermed. 32 (2006) 871-885.

[31] M. Chebbi, B. Azambre, L. Cantrel, A. Koch, J. Phys. Chem. C 120 (2016) 1869418706.

[32] N.E. Bogdanchikova, M.N. Dulin, A.V. Toktarev, G.B. Shevnina, V.N. Kolomiichuk, V.I. Zaikovskii, V.P. Petranovskii, Stud. Surf. Sci. Catal. 84 (1994) 1067-1074.

[33] A.M. Fonseca, I.C. Neves, Microporous and Mesoporous Mater. 181 (2013) 823-87.

[34] D. Jaumain, B-Li, Su, Catal. Today 73 (2002) 187-196.

[35] B.S. Choi, G. I. Park, J. H. Kim, Adsorption. 7 (2007) 91-103.

[36] R.G. Pearson, Inorg. Chem. 27 (1988) 734-740.

[37] J. Olmsted, G.M. Williams, Chemistry: "The Molecular Science", second ed., Wm. C. Brown Publishers, Iowa, 1997.

[38] J.M. Lopez, M.V. Navarro, T. Garcia, R. Murillo, A.M. Mastral, F.J. Varela-Gandia, D. Lozano-Castello, A. Bueno-Lopez, D. Cazorla-Amoros, Microporous Mesoporous Mater. 130 (2010) 239-247. 
[39] T.M. Nenoff, M.A. Rodriguez, N.R. Soelberg, K.W. Chapman, Microporous and Mesoporous Mater. 200 (2014) 297-303.

[40] B. Azambre, A. Westermann, GI. Finqueneisel, F. Can, J.D. Comparot, J. Phys. C 119 (1) (2015) 315-331.

[41] A. Westermann, B. Azambre, M. Chebbi, A. Koch, Microporous and Mesoporous Mater. 230 (2016) 76-88.

[42] T. Kodaira, T. Ikeda, H. Takeo, Eur. Phys. J. D. 9 (1999) 601-604. 